\title{
"Las cosas singulares de piedras, animales, plantas": La formación y el funcionamiento de la red imperial española de remesas centíficas en el Virreinato del Río de la Plata',2
}

\section{Magnus Roberto de Mello Pereira ${ }^{2}$}

RESUMEN: El presente artículo acompaña el proceso de remesa de especímenes animales y vegetales de la región administrativa del Virreinato del Río de la Plata para las instituciones científicas españolas, tales como el Real Gabinete, el Real Jardín Botánico y las menageries del Retiro y de Aranjuez. El propósito fue intentar sorprender esas remesas en el exacto momento en que tales instituciones y sus redes de recolección estaban siendo creadas, buscando explicar las lógicas que las presidían, en un momento en que se mezclaban propósitos de orden económico; la cultura de la dádiva, típica del Antiguo Régimen; con las modernas prácticas científicas que estaban en construcción.

PALABRAS CLAVE: Jardines Botánicos, Museos de Historia Natural, Flora y Fauna de América, Redes Científicas.

ABSTRACT: This article follows the process of shipping animal and vegetable species from the administrative region the Vice-royalty of Río de la Plata to the Spanish scientific institutions, such as the Real Gabinete, the Real Jardín Botánico and the menageries of Retiro and Aranjuez. The objective was to grab such shipments at the exact moment these institutions were being created, in order to make explicit their presiding logic, which mixed economicist purposes, the culture of gift, typical of the Ancien Regime, with modern scientific practices which were, in turn, being built.

KEYWORDS: Botanical Gardens, Museums of Natural History, Flora and Fauna of America, Scientific Networks.

RESUMO: $\bigcirc$ presente artigo acompanha o processo de remessa de espécimens animais e vegetais da região administrativa do Vice-Reino do Rio da Prata para as instituições científicas espanholas, como o Real Gabinete, o Real Jardim Botânico e as menageries do Retiro e de Aranjuez. $\bigcirc$ propósito é tentar surpreender essas remessas no exato momento em que tais instituições e suas redes de recolha estavam sendo criadas, buscando explicitar as lógicas que as presidiam, num período em que se mesclavam propósitos economicistas, a cultura da dádiva,
1. Este trabajo es resultado de investigaciones financiadas por el Conselho Nacional de Desenvolvimento Científico e Tecnológico (CNPq) y por la Fundação Araucária - Paraná, y tuve colaboración.

2. Agradezco el apoyo de la .de la historiadora Ana Lúcia Rocha Barbalho da Cruz.

3. Profesor del Departamento de Historia de la Universidad Federal de $\mathrm{Pa}$ raná, Becário del CNPQ e integrante del Centro de Documentação e Pesquisa de História dos Domínios Portugueses de la Universidade Federal do Paraná (CEDOPE / UFPR). E-mail: <magnus@ufpr.br> 
típica do Antigo Regime e as modernas práticas científicas então em construção.

PALAVRAS-CHAVE: Jardins Botânicos, Museus de História Natural, Fauna e Flora da América, Redes Científicas.

Naturalia, mirabilia et monstrosa

A partir de la segunda mitad del siglo XVI, creció en Europa el interés por el coleccionismo de curiosidades exóticas. Dicho interés no era fortuito. El establecimiento de vías navegables en dirección al Nuevo Mundo y al Oriente promovió una verdadera revolución en la cosmología del hombre europeo al revelar para él sociedades humanas diversas de la suya y un mundo físico insospechado. Estos nuevos horizontes, presentados por los grandes viajes, promovieron también la extensión de los conocimientos en Historia Natural. Los viajeros del siglo XVI, naturalistas por casualidad, o especialmente escogidos por sus conocimientos, llevaban a Europa artefactos producidos por culturas alienígenas, muestras de flora y fauna desconocidas e inexploradas para alimentar las colecciones de naturalia, mirabilia y monstrosa, acumuladas por un ávido público de curiosos y eruditos.

A lo largo del tiempo, estas colecciones fueron designadas por una nomenclatura que por si sólo excita la imaginación y anuncia un universo exótico, único y fascinante: Cámara de las Maravillas, la Artifitialia, Naturalia et Mirabilia, Kunst-und Wunderkammern, Teatro del Mundo, Teatro de la Naturaleza, Gabinete de Curiosidades, Vivarium, Harboretus, Plantarium. Entre los siglos XVI y XVIII, estos fueron algunos de los sugestivos nombres utilizados para designar las espléndidas colecciones de los europeos ricos, constituidos de miles de ejemplares producidos por la mano del hombre o por los prodigios de la naturaleza. Sea por la singularidad o por la extrañeza, por la belleza o por el exotismo, por atributos fantásticos, mágicos o curativos, por la novedad o por la antigüedad, los adeptos del coleccionismo, a lo largo del tiempo, disputaron, en un creciente mercado, los más diversos objetos venidos de los cuatro rincones del mundo o de las más remotas épocas.

Muy temprano, la realeza europea fue atraída para esta nueva forma de coleccionismo y se dio cuenta de que ella tenía atributos que iban más allá de la simple acumulación de curiosidades. Las Wunderkammern de principio de los tiempos modernos, al reunir en un mismo espacio monedas y estatuas de la Antigüedad, instrumentos mecánicos y astronómicos, globos terrestres y esferas celestes, relojes y un sin número de maquinarias encomendadas por hábiles artesanos, además de plantas, animales y minerales extraños, cumplían un papel político importante. Gabinetes, huertos y las menageries destinadas a los animales, además de divulgaren la ciencia como forma superior de conocimiento, fueron utilizados como instrumentos de afirmación del poder de las casas reinantes. 
Los Medici fueron ávidos coleccionistas y muchos príncipes electores alemanes organizaron gabinetes de mirabilia. Casi siempre, estas grandes figuras aliaban el coleccionismo con el mecenato de las ciencias. La formación científica y el entusiasmo por las maravillas de la Naturaleza y de la Filosofía Natural, desde finales del siglo XVII, se convirtieron en un índice de modernidad abrazado por la realeza. En Francia, Luís XV se interesaba por mirabilia y el Delfín recibía lecciones de Física. En el siglo XVIII, ser "filósofo" era casi siempre una obligación para los monarcas europeos. El rey Inglés, Jorge III, se dedicaba a la Botánica; D. Juan V, de Portugal, enriquecía su gabinete de curiosidades y observaba demostraciones astronómicas; Víctor Amadeo III repetía, en Italia, los experimentos científicos del abad Nollet. Liebniz animaba a Pedro el Grande, a patrocinar la exploración sistemática de su Imperio: "donde se encontrarán [...] muchas plantas, animales, minerales y otras naturalia que todavía no han sido descritas" ${ }^{4}$. Así, gran parte de los museos de historia natural tuvieron su origen en las colecciones privadas de las casas reinantes, abiertas inicialmente a un público restringido y, más tarde, al público en general. Una vez que partes significativas de estas colecciones proceden de regalos enviados a la realeza, no podemos olvidar que ellas fueron compuestas bajo el signo del patronato y de las cadenas de dádivas, cosas típicas de la cultura política del Antiguo Régimen.

Con el coleccionismo de animales vivos, el proceso fue similar. Giovanni di Lorenzo de Medici, el papa León X, tenía una menagerie en el Vaticano que incluía pájaros tropicales, leones, leopardos, osos, monos, civetas y un elefante asiático llamado Hanno, un regalo de D. Manuel de Portugal ${ }^{5}$. Los Habsburgo de España, desde el siglo XVI, utilizaban los reales establos del Palacio de Aranjuez para crear animales exóticos. Felipe IV hizo construir, en 1633, una leonera en instalaciones adjuntas al Palacio del Buen Retiro. En 1665, Luis XVI creó en Versalles una menagerie que serviría de modelo, como todo lo que hacía, a la realeza del resto de Europa. Los Habsburgo de Austria mantenían colecciones de animales desde el siglo XV. Francisco I de Austria, sin embargo, remodeló la menagerie de Schönbrunn a la moda del Rey Sol, para regalar a su esposa María Teresa, en 1752.

En España del siglo XVIII, Felipe IV, el primer rey Borbón de España, dio continuidad al coleccionismo animal, siguiendo el gusto de sus predecesores Habsburgos. Reformó la leonera del palacio del Retiro y se dedicó a traer grandes felinos de las colonias. Ordenó al virrey de Perú, que remitiese a la Corte las parejas de los animales más feroces que encontrase "para la diversión del ánimo y ocupar los ratos que puedo dar al tiempo, después de haber asistido a la continua ocupación y despacho de tantos negocios como dependen del Gobierno de esta Monarquía"6.

Los jardines botánicos, a su vez, no nacieron tan cercanos al poder regio. Ellos fueron frutos de un largo proceso de transición de los jardines medievales, destinados al cultivo de especies medicinales, a los jardines setecentistas de coleccionismo, estudio y aclimatación. El Orto Botánico de Pisa, fundado en 1543, es considerado el más antiguo jardín botánico moderno, pero fue en Padua, en
4. Cf. Françoise Waquet (1996, p.171).

5. Cf. R. J. Hoage y William Deiss (1996. p.14).

6. Cf. Fernando Soler Jardón (1947, p. 503). 
7. Cf. Jean-Pierre Clément (1993, p.15).

8. Cf. Pierre Huard y Ming Wong (1964, p.147)

9. Cf.Jorge Cañizares-Esguerra (2006, p.27).

10. Cf. Harold J Cook (2007).

11. Cf. Giuseppe Olmi (1996, p.272-277, 274).
1548, que se hizo la integración entre el huerto y la Universidad. Este modelo fue adoptado por otras universidades italianas, a ejemplo de la de Bolonia, y de alli se difundió hacia el norte de Europa. La de Leyden creó su huerto en 1587 y la de Montpellier, en 1593.

A lo largo del siglo XVII, estos jardines pasan de la condición de local de cultivo de plantas medicinales, para la de estudio de botánica y de coleccionismo vegetal. Cada vez más, ellos se tornaban el destino de las plantas exóticas enviadas de las Américas y del Oriente. El jardín botánico de la Universidad de Ámsterdam es un buen ejemplo de este pasaje. Para caracterizar la mudanza de sus propósitos y extensión, cambió su nombre de Hortus Medicus para Hortus Botanicus?. El Jardin Royal des Plantes Médicinales, creado por Luis XIII, en 1635, asumió lentamente un otro propósito y abandonó la designación Médicinales, para convertirse en el Jardin des Plantes u, oficialmente, el Jardin du Roi, en 171 8. No podemos olvidar, como lo advierte Cañizares-Esguerra, que el desarrollo de la botánica no se dio solamente en estos espacios creados a partir de la tradición humanista.

The genealogy of the botanical garden (from medicine to ornamentation to plantation agriculture) does not pay sufficient attention to developments in sixteenth-century Portugal and Spain, however, for early modern botany was rooted in the entrepreneurial, utilitarian efforts of apothecaries in gardens and hospitals in Seville, Lisbon, Goa, and New Spain as the humanist culture of the medical faculties of Padua, Leiden, and Montpellier?.

Semejante tesis sostiene Harold Cook, para quien el énfasis en valores como objetividad, descripción y acumulación, propias del gran comercio renacentista, proporcionaron las bases epistemológicas sobre las cuales fueron construidas las ciencias modernas ${ }^{10}$.

De cualquier forma, en lo que respecta al coleccionismo botánico, estaban siendo dados los primeros pasos hacia un nuevo nivel epistemológico. Se iniciaba el proceso, a través del cual, sea por la reconfiguración de antiguos huertos médicos, académicos y de tradición utilitaria ibérica, sea por la creación de nuevos, ellos asumirían el carácter de jardines botánicos imperiales, financiados por la realeza.

Si a través de la exposición de sus colecciones de naturalia, mirabilia y monstrosa, los soberanos buscaban dar un testimonio espectacular de su magnificencia y modernidad; por otro lado, estas colecciones enciclopédicas no dejaban de ser instrumentos de conocimiento. A pesar de agruparen especímenes y curiosidades en un aparente caos, o tal vez por esto mismo, los gabinetes, jardines y menageries fueron herramientas que permitieron el desarrollo de un conocimiento con pretensiones universales. En cierto sentido, constituir colecciones enciclopédicas, en aparente confusión y desorden, equivalía a "crear a su alrededor un 'pequeño mundo', un 'microcosmo', que, diferentemente del gran mundo, del mundo exterior, podía ser controlado, medido y dominado"11.

De las colecciones de naturalia, mirabilia et monstrosa del siglo XVI a las instituciones de coleccionismo de Historia Natural del siglo XVIII, ocurrirán una serie de mutaciones que, de modo general, llevaron a una mayor valorización del carácter 
científico de las colecciones en detrimento del carácter espectacular o exótico de sus acervos ${ }^{12}$. Sin embargo, no fue un proceso linear, una vez que, desde el siglo $\mathrm{XVI}$, naturalistas, médicos y farmacéuticos ya privilegiaban el carácter especializado de sus colecciones. "De la misma forma que, en el siglo XVIII, el carácter más especializado de los museos de historia natural no impidió que ricos propietarios continuasen a mantener y aumentar sus colecciones de variedades curiosas" ${ }^{\prime 13}$.

La transición del coleccionismo de curiosidades para otro cuyo carácter hoy reconocemos como científico, no se dio sin gran dificultad, una vez que era la noción de dádiva que determinaba cuales eran los ítems coleccionables. Por lo que hoy sabemos, no todo podía ser dado como regalo. Una buena ofrenda, sobre todo cuando es dada a un rey, tenía que ser algo notable y excepcional. La consecuencia es que el coleccionismo de los gabinetes de curiosidades, como el propio nombre dice, tendía a crear un 'microcosmos' caracterizado por la excepcionalidad de las cosas. La gran tarea del siglo XVIII fue pasar de la esfera restricta del ítem excepcional para la noción ampliada de que todo puede ser objeto de colección, clasificación y estudio, pero no debemos perder de vista que la cultura del patronato y de las cadenas de dádivas continuaban muy vivas, cuando no, determinantes en la composición de muchos acervos que se pretendían científicos.

Los Complejos de Historia Natural

El principal responsable por elevar las actividades coleccionistas a un nuevo nivel fue Carlos Linneo. El naturalista sueco consolidó su reputación científica después de peregrinar por la lejana Laponia, colonia ártica de Suecia. Posteriormente, asumió el mando del antiguo huerto medicinal de la Universidad de Uppsala, creado en 1655, adaptándolo a sus nuevos diseños. En este modesto jardín, elaboró su gran proyecto de levantamiento, clasificación y aclimatación universal. Con el fin de obtener especímenes de minerales, de fauna y de flora, esparció sus discípulos en peregrinación por los cuatro rincones del mundo, construyendo así una gran red de informaciones científicas. Muchos de estos naturalistas viajeros a servicio de Linneo eran pastores luteranos embarcados como capellanes y/o médicos en navíos comerciales suecos, daneses, holandeses e ingleses. A través de esta red de naturalistas viajeros, consiguió, entre 1746 y 1772, recoger especímenes e informaciones de las más variadas regiones del mundo ${ }^{14}$. Por fin, el reconocimiento de su merito era tal, que prácticamente todos los involucrados con ciencias naturales procuraban congregarse a su red. Intercambiar correspondencia con el naturalista sueco o enviarle ejemplares, era casi una obligación para aquellos que buscaban reconocimiento en el ambiente científico de la época. Además, Linneo llegó a estar implicado indirectamente en el proceso de disciplinar las remesas y la exposición de productos naturales. Bajo su orientación, dos alumnos de la Universidad de Uppsala elaboraron manuales destinados a instruir las actividades de recolección y organización de colecciones de historia natural. David Hultman, publicó en 1753 un manual de instrucciones destinado a orientar la organización de los gabinetes y
12. Sobre la trayectoria histórica de los gabinetes de curiosidades, ver Lorelai Kury y Carlos Z Camenietzki (1997).

13. Cf. Ana Lúcia R.B. Cruz (2004, p.60).

14. Sobre la red de discípulos de Linneo, ver Georges Ueberschlag (1977). 
15. Cf. David Hultman (1753).

16. Cf. Ericus Nordblad (1760 [1759] ).

17. Esta estructura establecida por Linneo, y después reproducida por toda Europa, ejemplifica con perfección los conceptos de "centros de cálculo" y "redes" desarrolladas por Bruno Latour (2000).

18. Sobre el carácter nacionalista del ideario de Linneo, ver Lisbet Koerner (2000).

19. Ver Antonio Lafuente y Antonio Mazuercos (1987).

20. Cf. Charles-Marie La Condamine (1745). museos de historia natural de Suecia, incluyendo los del Rey y la Reina ${ }^{15}$. En 1759, Eric Anders Nordblad defendió y publicó la tesis Instructio peregrinatoris, iniciando una nueva generación de manuales generales de recolección que atendían a los propósitos científicos linneanos ${ }^{16}$.

A través de este conjunto de acciones, que llevaban en sí un propósito universalizante, Linneo dio bases sistemáticas a lo que vendría a ser el gran proyecto patrocinado por las coronas europeas de (re)conocimiento del mundo, a través del levantamiento y de la catalogación general de la flora, la fauna, los minerales e de los 'hombres'17. Además, en el mismo período, los avances de la astronomía permitieron que el globo fuese cartografiado en un nuevo nivel de detalles y precisión. Este proyecto integraba una nueva ola expansionista europea, que no apuntaba sólo al conocimiento por el conocimiento. También no era este el propósito de Linneo, una vez que sus ideas incluían fuertes componentes utilitaristas y de nacionalismo imperial sueco ${ }^{18}$. En la actualidad hay un consenso historiográfico de que las motivaciones científicas de esta nueva fase expansionista, nacieron y se desenvolvieron inextricablemente vinculadas a propósitos utilitarios e imperiales.

En 1735, Francia envió al Virreinato del Perú un conjunto de astrónomos y naturalistas, bajo el mando de Louis Godin, en una expedición cuyo principal objetivo era hacer mediciones astronómicas destinadas a verificar si era correcta la hipótesis de Newton sobre el achatamiento de la Tierra en las regiones polares ${ }^{19}$. Esta fue la primera gran expedición científica del siglo XVIII y se tornó más conocida por las aventuras de uno de sus miembros, Charles-Marie de La Condamine, que por sus importantes resultados científicos. ${ }^{20}$ Sin embargo, son las expediciones navales inglesas contra las colonias españolas (1740-1744), bajo el mando del comodoro George Anson, que generalmente son tomadas como punto de partida del nuevo proceso europeo de expansión científico-imperial. Estas expediciones militares, que formaban parte de la guerra de sucesión austriaca, desencadenaron una carrera colonial en que las principales potencias europeas buscaron reposicionarse a escala global. El proceso ganó impulso con la Guerra de los Siete Años (1756-1763), en la cual los conflictos entre Inglaterra y Francia superaron el ámbito europeo y se expandieron hasta América del Norte, Caribe, Senegambia e India. Formaron parte de este clima de guerras estratégicas setecentistas las invasiones españolas de la parte sur de las posesiones portuguesas en América, en las décadas de 1760 y 1770. Cada vez más, las colonias pasaron a ser el teatro de las guerras europeas.

Desde entonces, las islas y pasos oceánicos, como las Malvinas y el Estrecho de Magallanes, fueron considerados puntos estratégicos de expansión colonial y, al mismo tiempo, se convirtieron en espacios privilegiados de observación científica. Francia, Inglaterra y España organizaron varias expediciones marítimas de exploración, buscando descubrir y tomar posesión de estos locales. Áreas poco exploradas, como la costa patagónica y la costa oeste de América del Norte, también se convirtieron en blancos de la voluntad expansionista de las potencias europeas. Los archipiélagos del Pacífico, bien como las grandes extensiones aisladas 
del extremo sur, hasta entonces libres de la presencia colonial, fueron regularmente exploradas y sometidas al dominio europeo. La acción más espectacular fue la ocupación inglesa de Australia y de Nueva Zelanda.

Desde un punto de vista científico, el resultado más significativo de estas expediciones, fue la consolidación del paradigma epistemológico compuesto por el trípode: (1) modelo taxonómico linneano, (2) peregrinaciones imperiales europeas y (3) complejos de Historia Natural (jardín-museo-menagerie); lo cual pasó a ser reproducido en todas partes. Joseph Banks, después de participar como botánico en uno de los viajes de Thomas Cook, se convirtió en figura central de los Royal Botanic Gardens de Kew, y pasó a controlar la política de envío de naturalistas en las expediciones despachadas por el Almirantazgo para todos los continentes ${ }^{21}$. A pesar de menospreciar la taxonomía de Linneo, Buffon realizó un proceso similar de recolección, a partir del Jardin du Roi. En España, el Real Gabinete y el Real Jardín Botánico de Madrid, pasarían a centralizar la política imperial de recolección y catalogación de especímenes. En Portugal, Domingos Vandelli seguiría exactamente el mismo modelo, al implementar, desde 1768, el Museu e Jardim Botânico da Ajuda. Por toda Europa, e incluso en algunas colonias, fueron creadas nuevas instalaciones y las antiguas fueron adaptadas para satisfacer las nuevas demandas.

A finales del siglo XVIII, ganó fuerza la noción de que en vez de explorar los productos exóticos en sus locales de origen, ellos deberían ser traídos y adaptados a las condiciones europeas. Se imaginaba que la criación de animales y especies agrícolas alienígenas, como la vicuña y la patata, podrían causar una revolución productiva y alimentaria en Europa ${ }^{22}$. En países como Francia, donde tuvo fuerza el dirigismo colbertista y después, las ideas fisiocráticas, esta modalidad de cientificismo utilitario ejerció particular atracción. En aquel país, este ideario se convirtió en política de estado, lo que resultó en una nueva modalidad de huertos y menageries: los jardines de 'aclimatación'23. Según Michel Osborn:

\footnotetext{
The term first appeared in eighteenth-century France, where it was associated with the botany of exotic plants and with Lovis-Jean-Marie Daubenton's efforts to introduce merino sheep into the country. Daubenton traveled to Spain to study sheep breeding, experimented on wool quality and breeding at numerous sites in France, and dreamed of acclimatizing the tapir, peccary, and zebra. During the Enlightenment, but also in the revolutionary era, the idea resonated with calls for utilitarian science. The Abbe Feraud wrote in 1787 that "acclimate" was a new word attributed to Guillaume-Thomas Raynal, a critic of European methods of colonization. According to Feraud, it signified being "habituated to a climate" 24 .
}

Una fervorosa adepta de la aclimatación de especies fue Josefina de Beauharnais, la emperatriz de Francia. En 1799 - por lo tanto, antes de Napoleón haber se convertido en emperador -, ella compró la propiedad de Malmaison y allí hizo construir invernaderos y menageries. Fue una ávida coleccionista de animales y plantas con el fin de adaptarlos a las condiciones europeas y hacerlos económicamente útiles a Francia.
21. Cf., Sylvie Lacroix (1990) y Richard Harry Drayton (2000, p. 85 e ss).

22. Lorelai Kury (2004, p. 122) recuerda que la difusión de la patata en Europa simbolizó la victoria de las ideas de aclimatación.

23. Sobre las teorías de aclimatación, ver Warwick Anderson (1992) y Michael A. Osborne (2000).

24. Cf. Michael A. Osborne (2000, p.137). 
25. Cf. Magasin Encyclopédique (1805, p.445).

26 Cf. Antonio Gonzáles Bueno y Raúl Rodríguez Nozal (2000, p.14-16).

27. Cf. Real cédula... (1787).

28. Sobre este jardín, ver Antonio González Bueno (1985).

29. Ver Antonio Cabral Chamorro (1995).

30. Cf. Manuel de Godoy (1836, v. 3, p.362).
Il existe à Malmaison une multitude d'animaux de la plus grande rareté. Les lamas mâle et femelle qui y ont été amenés il y a deux ans ont produit cette année un petit très-vigoureux et très bien portant. Cela donne à penser que si l'on parvenait à introduire chez nous la vigogne elle y multiplierait aussi puisque c'est un animal qui diffère très peu du lama SM I'Impératrice désirant que ses riches collections de plantes et d'animaux servent à l'avancement des sciences a ordonné que Malmaison serait ouvert aux membres de l'Institut et aux administrateurs du Musée d'histoire naturelle ${ }^{25}$.

En España, la idea de aclimatación ya estaba muy presente en la Real Cédula de 1787, que reglamentaba el funcionamiento del Real Jardín de Cartagena. Este jardín, creado por la Marina, debería servir a esta tarea por estar situado en las regiones calientes del sur de España, cuyo clima, se imaginaba, sería más propicio al cultivo de vegetales exóticos ${ }^{26}$. Los esquejes y semillas enviadas por las expediciones botánicas, deberían ser cultivadas en aquel Real Jardín hasta que "se acostumbren insensiblemente á nuestros climas, y propagandose se transplanten y connaturalicem, en los terrenos de Espanã que sean mas adecuados a su naturaleza" 27 .

Manuel de Godoy, valido de Carlos IV y el principal aliado de Napoleón en España, también ordenó la construcción de un jardín de aclimatación: el Jardín Botánico de la Paz, llamado así debido al título de Príncipe de la Paz, con que el rey le había agraciado ${ }^{28}$. Este huerto, situado en Sanlúcar de Barrameda, en Andalucía, fue diseñado con el propósito de la aclimatación de plantas y animales venidos del universo colonial españo|29. Duró sólo hasta 1808, cuando vino la ruptura de la alianza franco-española y el 'príncipe' fue derrocado. La turba en furia destruyó todo lo que fuese asociado a Godoy, incluso el jardín. Según sus propias palabras:

Por el mismo tiempo comenzaba ya á prosperar el magnífico jardín de aclimatación de San Lúcar de Barrameda, obra mia predilecta, donde las mejores plantas, árboles y arbustos de los trópicos tomaban derecho de ciudad entre nosotros, jardín precioso y criadero de una gran esperanza, que asegurada ya por el año de 1808, lo arrancaron de cuajo las plebes engañadas y aturdidas de mis furiosos enemigos ${ }^{30}$.

Como se puede ver, a través de los muchos indicios presentados hasta ahora, España participó activamente del largo proceso de constitución de las ciencias de la naturaleza, que se inicia en el Renacimiento con el acúmulo y estudio de las colecciones de naturalia, mirabilia y monstrosa, y se consolida en el aparato científico setecentista de colecta, exhibición y estudio de productos naturales.

El propósito del presente artículo es pensar la manera a través de la cual la región platense estuvo insertada en la política científica española, y para esto hay que tener en cuenta que esta inserción se hizo a través de una "red de informaciones y de remesas cientificas", centrada en algunas instituciones como el Real Gabinete, las menageries del Retiro y de Aranjuez, el Real Jardín Botánico y, más tarde, el Real Jardín de Cartagena y el Jardín de la Paz. España participaba del mismo modelo que se tornó hegemónico a partir del siglo XVIII, en que la producción imperial de 
conocimiento pasó a estar organizada, de acuerdo con la historiadora Lorelai Kury, "según una lógica de redes tejidas alrededor de centros de producción de conocimiento y de elaboración y redistribución de productos científicos" ${ }^{\prime \prime}$.

El imbricar de prácticas e instituciones que se formaron en aquel tiempo sugiere, por si sola, la metáfora de una gran trama, que fue tematizada por Bruno Latour, y resultó en el desarrollo de algunas nociones, como la de red científica, que son de gran interés para el entendimiento del proceso ${ }^{32}$. El uso de la palabra metáfora es intencional, pues las jergas pesadas de la teoría sociológica actor-red de Latour y sus variantes ocultan una buena dosis de sentido común. Además, hay que considerar que la constitución de las redes aquí discutidas pertenece a un proceso dotado de historicidad, que no puede ser pensado a través de raciocinios anticipados y de enfoques triunfalistas de la ciencia. Si es posible la concepción, propuesta por Latour, de que el desarrollo de las prácticas científicas se produce a través de la transformación de los saberes corrientes en datos abstractos, fijos y desconectados de la cultura que los produjo, también es importante pensar que la ciencia moderna se desenvolvió en interacción con la cultura política del Antiguo Régimen, en la cual la dádiva y la reciprocidad tenían pesos determinantes. Como advierte Antonio Manuel Espanha:

Esta importancia del don y de la beneficencia - y de las correspondientes gratitud y actitud de servicio - ha sido también constatada por la literatura sociológica más reciente en materia de network analysis (la cual ha sido ya objeto de variopinta aplicación historiográfica). En ella se habla principalmente de "redes sociales" a la hora de describir el modo en virtud del cual los agentes distribuyen recursos socialmente escasos (recursos económicos, empleos, honores y distinciones sociales, saber e información). Cada red puede ser considerada como un circuito social en el que se llevan a cabo intercambios (exchanges, transactions) de servicios, tanto actuales como virtuales. Si los intercambios son desiguales (o asimétricos), la parte acreedora gana en ascendencia, dando entonces origen a una relación de poder. Esta situación de desequilibrio se expresa con mucha frecuencia a través de la idea de "amistad" - respecto del acreedor: significa buena disposición para hacer un favor sin exigencia expresa de devolución - y de "respeto", "solicitud" o "consideración" - respecto del deudor: significa buena disposición para hacer servicios futuros e indeterminados ${ }^{33}$.

Así, el uso de nociones como la de red científica no significa que serán abandonados estos otros aspectos de las "redes sociales" de producción y circulación del producto científico a la época. El impacto renovador de concepciones como don, dádiva y merced, derivados del clásico ensayo del antropólogo Marcel Mauss (1974) ha sido intenso en la historiografía de las últimas dos décadas ${ }^{34}$. Hace casi un siglo, cuando desarrolló su estudio sobre la dádiva entre los nativos del Pacífico y de América del Norte, el propio Mauss ya indicaba para la aplicación a la Europa del Antiguo Régimen de las nociones que había desarrollado. Dar y recibir dádivas eran actos que se insertaban en cadenas de obligaciones recíprocas inherentes al propio funcionamiento de la sociedad europea. Como resultado, la noción de red de dádivas es tan o más pertinente para el entendimiento del proceso que lo de rede científica. A pesar de esto, en
31. Cf. Lorelai Kury (2004, p.111).

32. Ver, en especial, Bruno Latour (2000).

33. Cf. António M Hespanha (1993, p.156).

34. Principalmente, a partir de Natalie Zemon Davis (2000). 
35. Una excepción ejemplar es Michael Bravo (1999), que se contrapone a Latour pensando en términos de "geographical gift".

36. Cf. NuriaValverde Pérez (2007, p.19). la historiografía de las ciencias el uso de la noción de dádiva es aún poco común ${ }^{35}$.

La cuestión relativa a la formación de la red científica nos ha llevado a otro cuidado metodológico, el de no pensar aisladamente las remesas enviadas a las instituciones científicas españolas a partir de la región administrativa del Virreinato del Río de la Plata. Esto, porque tales remesas no ocurren de forma independiente, sino que integran un proceso. Para la historiadora Nuria Valverde, en el período en cuestión:

[...] se está creando la identidad del científico, se están construyendo los espacios, se están definiendo prácticas y se están articulando las distintas redes de transmisión de conocimientos. Con un ojo puesto en Europa y otro en las necesidades locales, los españoles irán definiendo la experiencia científica, destilándola como un sensus comunis, para llegar al siglo XIX con un discurso consolidado sobre la ciencia y el progreso, convirtiendo a los científicos en representantes de bien común, y la población en consumidora de su saber ${ }^{36}$.

Por lo tanto, el propósito fue intentar sorprender el envío de productos de la naturaleza en el exacto momento en que tales instituciones y sus redes estaban siendo creadas, de modo que quedasen explícitas las lógicas que las presidían, las cuales mezclaban propósitos de orden económica y la cultura de la dádiva, herencia del Antiguo Régimen, con aquella de la producción de artefactos abstractos, propia de los modernos padrones de prácticas científicas que estaban en construcción.

\section{España y las colonias en el Siglo XVIII}

En el Imperio Español, Felipe IV fue el rey que dio inicio a la recolección estatal sistemática de productos de la naturaleza, en tiempos de la creación de la Real Biblioteca. Una Real Cédula de 1712 ordenaba que Virreyes, Gobernadores y Corregidores de las colonias enviasen a aquella biblioteca "las cosas singulares de piedras, animales, plantas, yerbas y frutos de cualquier género que no sea común". Se trataba de una circular impresa, distribuida por todo el imperio español, lo que le dio el carácter de documento fundacional de una política general de recolección de naturalia, mirabilia et monstrosa.

Los pedidos de animales o plantas enviados a uno $\mathrm{u}$ otro gran funcionario colonial, eran comunes desde que empezó la expansión marítima española. Sin embargo, lo que se pretendía en aquel momento era agregar a las tareas de la red de administración imperial, la función de provisión de curiosidades y ejemplares de ciencias naturales. La insistencia en reunir "cosas singulares, raras, y extraordinarias, que se hallan en las Indias, y partes remotas", demuestra que la propuesta regia era establecer, anexo a la biblioteca, un típico gabinete prelinneano, congregando curiosidades provenientes de las colonias y de países exóticos como China y Japón. Animales también eran solicitados, lo que indica que, aparte de las fieras para el deleite de la corte, había la pretensión de coleccionar ejemplares curiosos de fauna exótica. Al crear una biblioteca y un gabinete de curiosidades traídas de las 
colonias, abiertos "para que qualquiera pueda libremente estudiar", el rey buscaba incentivar el interés por las cosas de la ciencia y, por supuesto, anunciar la grandeza del imperio que acababa de obtener, por fuerza de las disputas dinásticas de los Borbones. La gran España, aunque debilitada y amenazada por todos los lados, continuaba a ser el mayor imperio colonial europeo.

Un estudio de los efectos de esta Real Cédula todavía no se ha hecho. No se han investigado suficientemente la presteza y la intensidad con que los deseos del monarca fueron atendidos. Los gobernantes de Buenos Aires también recibieron una copia de esta circular impresa ${ }^{37}$. Sin embargo, la documentación disponible en el Archivo General de la Nación, no muestra que ella haya provocado acciones inmediatas y concretas de envío de especímenes a España.

Específicamente en lo que respecta a las remesas de animales, el historiador Centurión-Gómez verificó que en el siglo XVIII, hubo una disminución en el interés por felinos y otras grandes fieras. En 1774, Carlos III envió orden a los gobernantes coloniales para que ellos no enviasen más "tigres" a España, una vez que eran "de poco gusto del Rey, que se há mandado a matar a algunos que han venido" 38 . Sin embargo, no se detuvo el envío de grandes felinos a la corte. Centurión-Gómez contabilizó una remesa de 24 de estos animales, desde tierras americanas, entre 1731 y $1804^{39}$, los cuales acabaron alojados en la leonera del Retiro. Pero, a mediados del siglo hubo una mudanza de foco en las remesas y "comienzan a llegar como obsequio para la familia real animales cada vez más extranhos y curiosos por los que los naturalistas y los aficionados sentían uma inagotable fascinación"40.

La prevalencia de este nuevo espíritu puede ser observada en una remesa hecha por el gobernador de Buenos Aires, en 1751. D. José de Andonaegui envió a España un "pasaro nombrado Potu o Grifo, y el animalcito parecido al Urón"4l. La curiosa pareja de animales muy posiblemente era compuesta por un quique (Galictis cuja) ${ }^{42}$ y por un potu común (Nyctibius griseus) o alguna otra ave del género de los curiangós ${ }^{43}$. El Marqués de la Ensenada, secretario de la Hacienda, Guerra, Marina e Indias, se comprometió a comunicar que los animales habían llegado vivos a Cádiz y que serían remitidos a la Corte.

Esta mudanza de foco en el tipo de animales enviados es una indicación de que el paradigma linneano estaba siendo difundido en los medios científicos y administrativos, tanto en España, como en las colonias ${ }^{44}$. En 1755, Fernando VI, hijo y sucesor de Felipe $V$, ordenó la creación del Real Jardín Botánico de Madrid, que también era integrado por un gabinete de curiosidades. Este primero complejo de historia natural, creado por influencia de Antonio de Ulloa, se situaba en la Huerta de Migas Calientes, a las orillas del rio Manzanares. Su principal impulsor fue el cirujano y botánico José Quer, que reunió una colección con más de 2000 especímenes botánicos, colectados en España, enviados de las colonias u obtenidos por intercambio con otros jardines, practica que se había tornado común.

Como parte de este proceso, fue organizada la primera expedición científica española con bases linneanas: la Comisión de Demarcación de la frontera
37. AGN, sala 9, Interior, legajo 1, exp.1.

38. Cf. Bernardo Urbani y Ángel L. Viloria (2002).

39. Cf. Carlos Gómez-Centurión (2009, p.191).

40. Idem, p.192.

41. AGN, Sala 9, legajo 2150, 24-10-11.

42. Puede haber sido un irará, eirá, tayra o hurón mayor (Eira barbara) o hurón menor, quique o furão (Galictis cuja). Ver Félix de Azara (1802, p.172 y 182).

43. Estas aves nocturnas de la familia Nyctibiidae integraban la orden de los Caprimulgiformes, que recientemente fue eliminada por los zoólogos e incluida como una familia en la orden de los stigiformes (corujas). Incluye las aves que en Brasil son designadas de Noitibós, Curiangos y Bacuraus, y en América Hispánica, por añaperos, noctibios $y$ potus.

44. La difusión de la taxonomía linneana en los medios científicos españoles tuvo inicio con su utilización en el jardín botánico del Colegio de Cirugía de Cádiz, a partir de 1748; ver Miguel A. Puig-Samper (1993). 
45. Sobre esa expedición, ver Francisco Pelayo (1990) y Giraldo Lucena (1992).

46. Ver Jean-Baptiste Louis de Romé De L'isle (1767).

47. Sobre este proyecto, ver Luis Alfredo Baratas Díaz (1996).

48. Sobre la permanencia del coleccionismo de rarezas en el Real Gabinete, ver Paula De Vos (2009). amazónica, enviada al Orinoco, en 1754. Esta expedición, de carácter eminentemente estratégico, era consecuencia de la signatura del Tratado de Madrid, en 1750. Sin embargo, la participación de Pehr Löfling le dio el carácter de viaje científico ${ }^{45}$. Fue en este período que la corona ofició el sistema taxonómico linneano, imponiéndolo a todas las instituciones científicas españolas. Löfling era el discípulo estimado de Linneo e integraba la red linneana que sirvió de espejo para las potencias coloniales europeas. España incluyó dos médicos y dos diseñadores en la expedición, con el fin de formar un equipo propio para viajes científicos. El naturalista sueco hizo una amplia recolección de fauna y flora en la región, pero su muerte a principios de 1756, hizo con que los propósitos de exploración científica del territorio fuesen abandonados, restando sólo los estratégicos, de definición de las fronteras.

En la misma época, Pedro Franco Dávila, que era originario del Virreinato de Nueva Granada, intentó vender al monarca un enorme gabinete de historia natural y curiosidades, que había reunido en París, en dos décadas de intensa actividad coleccionista ${ }^{46}$. El enloquecimiento y muerte del rey impidió el avance de las negociaciones.

Carlos III, sucesor de Fernando, no sólo dio continuidad a las políticas de modernización de las ciencias en España, adoptadas por su hermano, como las amplió. Durante su reinado, Madrid pasó por diversas reformas urbanas, principalmente en la región del Prado Viejo, donde fue creado un gran eje que ligaba la ciudad al Palacio del Retiro. El Conde de Floridablanca, Secretario de los Despachos del Estado, procuró agrupar las principales instituciones científicas mantenidas por la corona, con el fin de crear un eje simbólico del mecenazgo regio a la ciencia y a la cultura: el Salón del Prado ${ }^{47}$. Allí fue construido el palacio donde debería quedar el Real Gabinete de Historia Natural, más tarde transformado en el Museo del Prado, y el Observatorio Astronómico. En 1774, tuvo inicio la transferencia del Real Jardín Botánico para la región, bajo el mando del botánico Casimiro Gómez Ortega. El nuevo jardín se inauguró en 1781.

El gabinete de curiosidades que sería instalado en el Prado era resultado de una segunda ronda de negociaciones con Pedro Franco Dávila. Arruinado financieramente, vendió parte de su colección de curiosidades en París. El restante fue "donado" a España, a cambio de una considerable pensión vitalicia y de la dirección del gabinete público que se crearía con la colección recientemente adquirida. El museo, después de algunos años de trabajos de organización interna, fue inaugurado al público en 1776, con el nombre de Real Gabinete de Historia Natural. A pesar de haber incluido Historia Natural en su nombre, y de los esfuerzos realizados por Dávila para dar este carácter al museo, por años continuó a ser visto principalmente como un gabinete de curiosidades. En las contribuciones espontáneas que recibió, continuaría teniendo gran peso las cosas singulares y aberraciones, como fetos monstruosos o conejos de cinco pies ${ }^{48}$. Además, el gabinete reunía colecciones de monedas y antigüedades históricas, pinturas y trajes exóticos, venidos de las colonias y del lejano oriente. En muchos casos era el propio rey que parecía 
no entender el énfasis que se quería imponer a la institución y mandaba para allí objetos de sus colecciones privadas que no siempre eran compatibles con tal énfasis.

Una de las tareas a que Dávila se dedicó en el período de organización del museo, fue la redacción de un librillo destinado a los virreyes y otros altos funcionarios de la corona de todo el imperio, con instrucciones básicas de recolección y conservación de "producciones curiosas de Naturaleza" que deberían ser enviadas a Madrid ${ }^{49}$. Este manual de instrucciones fue distribuido por todo el imperio, a través de una Real Orden circular del 10 de mayo de 1776, incluso a los diversos gobernadores locales del Virreinato del Plata. Al menos los gobernadores de Montevideo, Tucumán, Paraguay y del Plata acusaron su recibimiento50. En su mayor parte, la instrucción de Dávila era ocupada por una larga lista de "animales apetecidos para el Real Gabinete". Este énfasis en el reino animal hizo con que el gabinete funcionase en estrecha relación con la menagerie del Retiro. Los animales vivos enviados de las colonias fueron para allí trasladados y siempre que moría una especie considerada interesante, el equipo de taxidermia del gabinete era llamado para recoger el cuerpo del animal y prepararlo para exhibición.

El gusto de los miembros de la casa de Borbón por el coleccionismo no terminó con la creación de estas instituciones oficiales. El rey, la reina y el príncipe heredero continuaron a coleccionar naturalia, mirabilia y monstrosa. Principalmente en lo que respecta a los animales vivos, había cierta confusión entre lo que era para uso público y/o científico y lo que era de propiedad privada de los miembros de la familia reinante. La mayor parte de los animales enviados de las colonias llegaba a Madrid como ofrenda al propio rey. Por otro lado, el príncipe heredero era también un ávido coleccionista.

El Gabinete de Historia Natural (1752-1755), adjunto a la Real Casa de Geografía, que había comenzado a funcionar bajo la dirección de Antonio de Ulloa, fue disuelto y su colección fragmentada y distribuida por diversas instituciones. En 1766, fue ordenada la transferencia de "todas las curiosidades del Gabinete de Historia Natural, para el del Príncipe, que se iba estabelecer". Más tarde, algunas monedas llegan a ser retiradas del acervo del Real Gabinete para integraren la colección del Príncipe de Asturias, el futuro Carlos IV ${ }^{51}$. A veces ocurrían cambios en sentido inverso y era el príncipe que enviaba especies para enriquecer las colecciones del Real Gabinete, como fue el caso de una grulla pequeña (Grulla damisela), donada en $1783^{52}$.

El Príncipe de Asturias, que era entonces un joven de unos 18 años, tenía un interés especial por aves exóticas, vivas o empajadas. La condición de heredero del trono permitía que, para fomentar su colección privada, él recurriese a los mismos canales por donde fluía el coleccionismo científico oficial. La tarea de enriquecer el gabinete del príncipe fue cometida a uno de los más altos oficiales de la administración colonial española, Julián de Arriaga, el ministro de la Marina e Indias y contratador de Cádiz. En 1767, llegó una circular a Buenos Aires, remitida por el secretario, ordenando que fuesen enviados a España los "pasaros mas particulares en plumas que se crien en América", para satisfacer los deseos del Príncipe de
49. Cf. Pedro Franco Dávila (1776).

50. AGI, Indiferente General, Legajo 1549 , docs. 440 , $443,445,446$.

51. RGHN, doc. 129.

52. RGHN, doc. 701 . 
53. AGN, Sala 9, legajo 2197, 25-3-7.

54. AGN, Sala 9, legajo 2152, 24-10-13. La mencionada lista no fue archivada junto con la circular.

55. Cf. Carlos Gómez-Centurión (2009, p.187).

56. AGN, Sala 9, legajo 2197, 25-3-7.

57. Ver, Magnus R. M. Pereira y Ana Lúcia R. B. Cruz (2009).

58. Cf. Casimiro Gómez Ortega (1779).

59. C. Antonio Gonzáles Bueno y Raúl Rodríguez Nozal (2000, p.3).

60. Cf. Paula De Vos (2007, p.220).
Asturias $^{53}$. Esta circular que corrió por todo el imperio, propuso que si los pájaros no pudiesen ser enviados vivos deberían ser conservados de la mejor manera posible. Una nueva circular de Arriaga, en 1768, enviaba a Buenos Aires una lista de las "plantas, conchas y otras prezas que el Principe N'ro Sor desea para su Gavinete de Historia Natural, ampliando la coleccion de las demas especies particulares que produzcan essos Paises"54.

El historiador Gómez-Centurión constató que el envío de estas circulares destinadas a ampliar la colección del príncipe "constituyó el principal estímulo que empujó a las autoridades americanas a enviar durante las décadas siguientes toda clase de aves exóticas y de mamíferos raros, tanto para la colección particular del heredero como para la del soberano"55. En respuesta a la Real Orden fueron enviados algunos pájaros de la región del Plata, lo que "Ha merecido aprecio de S. M.". Sin embargo, Arriaga advertía que "haviendo llegado mui maltratados, se hace preciso observar la regla de sacarles las tripas salarlos, ó disecarlos para que conserven sus plumas y figura natural" ${ }^{\prime 56}$. Las remesas hechas por legos a menudo presentaban problemas de esta naturaleza, lo que llevaría a que fuesen elaborados manuales de instrucciones destinados a intentar asegurar que el material enviado no se perdiese ${ }^{57}$.

Simultáneamente a la organización de estas colecciones de curiosidades y de animales, la corona española patrocinaba la constitución del aparato oficial de coleccionismo botánico, este sí, mucho más próximo del paradigma científico linneano. Casimiro Gómez Ortega reinstaló el Real Jardín Botánico de Madrid en el Prado y fue el principal responsable por las expediciones españolas que se dedicaron a la recolección y al estudio de la flora de las tres Américas y de las Filipinas. Antes de reconstruir el huerto matritense, el naturalista estuvo en Francia y en Inglaterra para conocer los complejos de ciencias naturales de esos países. En 1779, Gómez Ortega publicó un opúsculo de instrucciones sobre el transporte de plantas por mar y tierra, destinado a mejorar la calidad de las remesas procedentes de la península hispánica y, especialmente, de la América española ${ }^{58}$. Según los historiadores Gonzáles Bueno y Rodríguez Nozal, la elaboración de las instrucciones tendría contado con la colaboración "del francés J. Dombey durante su estancia em Madrid, antes de embarcar con destino al Peru". "Luego se completaría lo escrito con nuevas normas distribuidas em circulares: la de 27 de agosto de 1789 sobre el modo de embalar, o la de 23 de febrero de 1792 recordando el cuidado em el riego para los plantones trás su arribo del duro viaje transatlântico" 59 . Estas circulares impresas fueron ampliamente distribuidas en España y en sus colonias.

La historiadora estadounidense Paula de Vos detectó que a lo largo de la década de 1780, fueron enviadas a las colonias 9 instrucciones circulares sobre el envío de plantas, semillas y maderas ${ }^{60}$. Ellas eran resultado directo de la reinauguración del Real Jardín Botánico, en 1781, y deben de haber llegado también al Virreinato de la Plata, aunque no encontremos todas disponibles en los archivos de Argentina. Por lo menos una de ellas, del 14 de marzo de 1783, integra la colección del Archivo General de la Nación. Se trata de una circular impresa, 


\section{INSTRUCCION}

SODRE EL a roDO AfAS SRGURA $T$ ECONÓMCO

DE TRANSPORTAR PLANTAS VIVAS

POR MaX $Y$ TERKa A $A$ LOS PALSES MAS DISTANTES

ILUSTRADA CON LASTINAS.

ANADESE

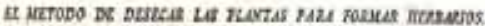

\section{DISPUESTA DE ORDEN DEL REY}

POR EL Da. D. CASIMIRO GOMEZ ORTEGA,

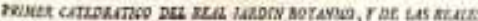

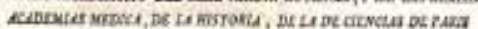

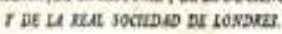
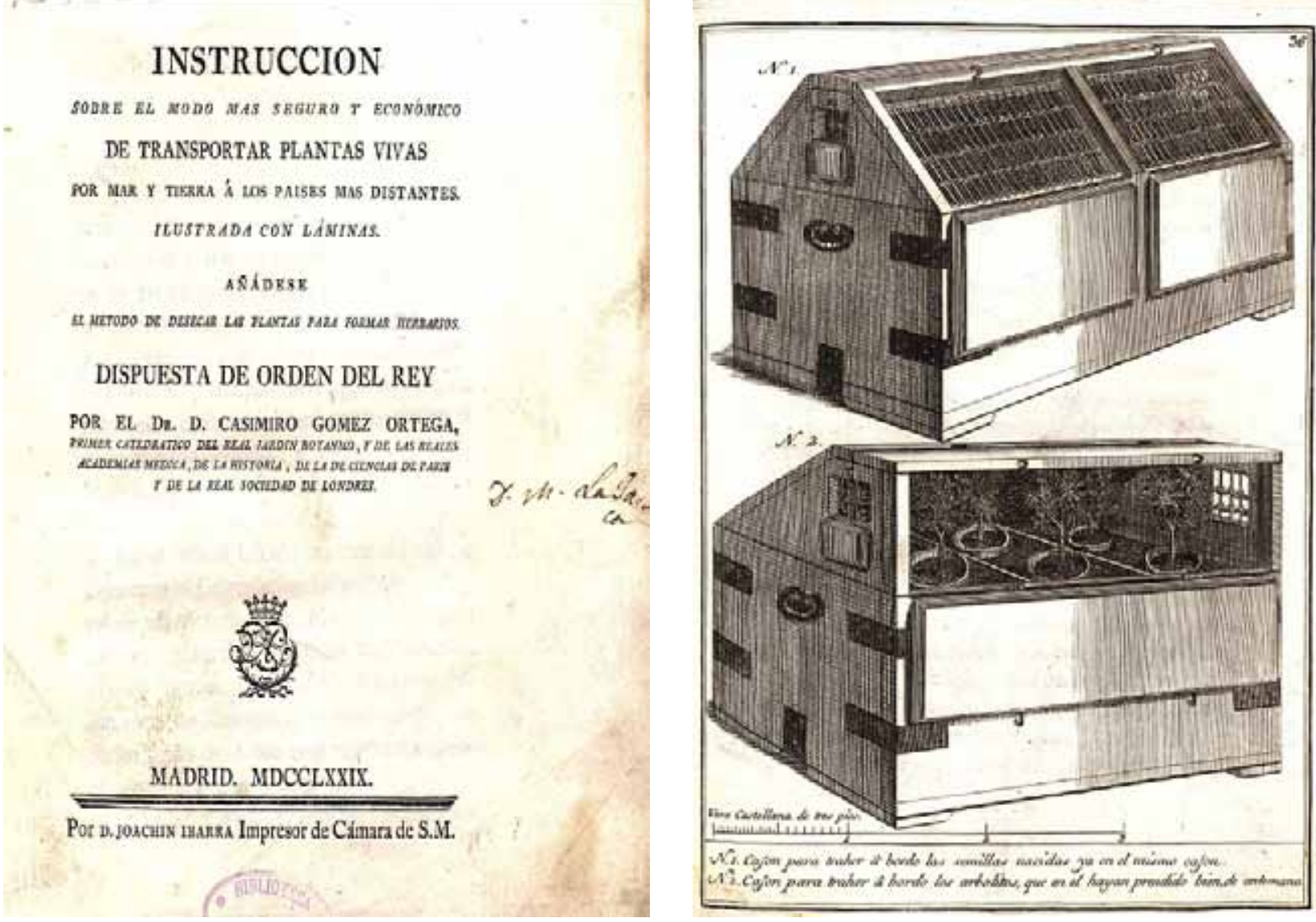

Figura 1 - La Instrución de Gómes Ortega

firmada por José Gálvez, Secretario de Estado y del Despacho Universal de Indias, que ordenaba el envío de esquejes y semillas a España. Esta orden reiteraba la obligación de que fuesen cumplidas las instrucciones de Ortega, que habían sido distribuidas "antes de la guerra", sobre el envío de esquejes a España.

Cinco años después, el virrey y los gobernadores de Montevideo, Tucumán, Salta y Charcas confirmaron a Madrid el recibimiento de la Real Orden del 27 de agosto de 1788, que solicitaba el envío de productos de historia natural y curiosidades. ${ }^{61}$ La documentación disponible en el Archivo de La Nación no demuestra, sin embargo, que esas circulares hayan provocado acciones inmediatas por parte de los oficiales de la corona. En general, lo que se observa es que las respuestas a las solicitaciones llegadas al Plata eran prácticamente nulas, principalmente cuando envolvían remesas de especímenes de flora. El deseo oficial de constitución de una red de abastecimiento de ejemplares para las instituciones científicas parecía no funcionar. El estudio de algunas de las remesas hechas a la época da pistas para el entendimiento de la lógica que las movía y el porqué predominaban los envíos de animales.
61. AGI, Indiferente General, legajo 1545 , docs. 175 , $179,187,189,195$. 
62. AGN, Sala 9, legajo 2165, 25-1-15.

63. Cf. Magnus Roberto de Mello Pereira (2002, p.39).

64. Cf. Carlos Gómez-Centurión (2009, p.186).

\section{承}

C idea de ir propagando en estos Reynos todos los boles y Plantas útiles de nuestras Indias, ha destinado el Rey varios parages de las Provincias de España en que se siembren vasplanten quantos vengan de esos Dominios; y en su conseyuencia me manda S. M. prevenir á V.C.como lo hago, que desde luego tome las providencias mas eficaces y oportunas á fin de indagar los Arboles mas especiales que hay en el distrito de su mando, tanto frutales, quanto de construccion, y de qualquiera otra clase que los haga estimables, como tambien las plantas medicinales, ó de particular hermosura que se conocieren, disponiendo que se cojan las semillas de aquellos y estas en perfecta sazon, y que al mismo tiempo se pongan algunos arbolitos y plantas en tinas, ó caxones de madera con buena tierra para que se me remitan sucesivamente en todas las Naves de guerra, y de comercio que vengan á los Puertos de esta Peninsula ; encargando mucho el cuidado á los Comandantes, ó Capitanes de los Buques, y arreglandose para hacer estas remisiones á la Instruccion impresa que compuso D. Casimiro Ortega, y que remití con Orden Circular antes de la guerra. Y á efecto de destinar aqui las semillas, arbolitos, y plantas que V. $\ell$. envíe á los parages, y terrenos convenientes, deberá acompañar á sus avisos una exácta noticia de sus nombres, propiedades, temperamento en que se crien, quándo se deban sembrar, ó trasplantar, y todas las demas advertencias que se regularen convenientes para que no se malogren los gastos, $y$ los benéficos objetos que el Rey se ha propuesto en esta importante, y utilisima resolucion; la que de su Real orden participo á V. C. para su exàcto, y puntual cumplimiento. Dios guarde á V. C muchos ańos. El Pardo 14 de Marzo de $178_{3}$.

D.

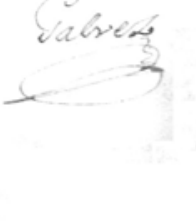

Figura 2 - Circular impresa, firmada por José Gálvez ${ }^{62}$

Al observar el proceso semejante de remesa de productos de la naturaleza de las colonias portuguesas para el Museo de Historia Natural de Ayuda, es posible percibir que la dinámica de las remesas envolvía propósitos más allá de los puramente científicos. Muchas veces recibidos como 'regalos' personales, estos envíos daban lugar a espera de un gesto de reciprocidad por parte del recibidor.

Un cargamento de pájaros exóticos, una caja con conchas raras, o para adentrar en el pequeño teatro de horrores de la época, una pareja de niños negros albinos o enanos, era frecuente sirvieren de introito a un pedido de promoción de un subalterno, o a una solicitación de retorno para casa, hecha por un obsequioso alto funcionario cansado del clima inhóspito de las colonias ${ }^{63}$.

Según Gómez-Centurión, en el imperio español no era diferente. Las dádivas cientificas enviadas por parte de los "virreys y gobernadores de Ultramar pretendían simplemente complacer al monarca y obtener de él alguna gracia, casi siempre una promoción en los empleos o un regreso rápido a la Península con un destino más apetecible"64. Mientras tanto, no sólo los altos funcionarios actuaban así. La práctica 
era común en todos los niveles de la jerarquía administrativa y entre los beneficiados con prebendas y monopolios, que, de forma indirecta, de ella participaban.

Al pedir ejemplares de fauna y flora, los dirigentes de las instituciones científicas españolas imaginaban que fuese posible establecer redes científicas. Sin embargo, los canales por donde fluían tales órdenes eran caracterizados por la cultura administrativa española, que se debatía en el interior de un doble influjo. De un lado la intención de construir un aparato de estado que debería ser moderno e impersonal, de cuño iluminista, y de otro, las prácticas características del Antiguo Régimen, que envolvían dádivas y lazos interpersonales. En esta compleja ecuación, durante mucho tiempo predominó el segundo factor, pues tenía más sentido enviar un animal exótico de presente al Rey, o a un integrante de la alta nobleza administrativa del imperio, que se envolver con complejos procesos de remesas científicas botánicas. Esto explica la amplia preeminencia de remesas de animales ${ }^{65}$. Se trataba de una cuestión de lógica y no de facilidad, pues hacer una de esas criaturas atravesar el océano acostumbraba ser muy complicado.

\section{Un Oso Hormiguero en la Corte}

A mediados de 1776, llegó a España una criatura rara venida del Plata, la cual, en la misma época, se haría famosa en los medios científicos europeos ${ }^{66}$. Manuel Basavilbaso, que detenía el monopolio del Correo de Buenos Aires, mandó de regalo a Carlos III un oso hormiguero bandera, oso hormiguero gigante o yurumíb67 (Myrmecophaga tridactyla).

Han enviado al Rey desde buenos ayres um Oso ormiguero; y habiéndole visto S. M. em su mismo cuarto y viendo lo manso que es, há mandado se lleve a ese Sitio [del Retiro] para que le ponga em algún quarto, ó outro parage conveniente, y se le trate en comida y em todo lo demás según el método que diga el conductor que há ido á llevarle ${ }^{68}$.

Debido a su alimentación altamente especializada, sólo el hecho de haber llegado vivo a Europa, ya representaba una hazaña científica. Intentos anteriores de envío de osos hormigueros habían fracasado por esta misma razón. Un ejemplar enviado desde Maracaibo, en 1751, que era alimentado con carne picada y sangre fresca de las reses sacrificadas en la travesía, no sobrevivió a esa dieta 69 . Félix Azara dice que "algunos han domesticado á la primera espécie [de oso hormiguero], y aun la han llevado viva á la España, dándoles miguitas de pan, carne picada, leche y harina dissuelta em agua"70. Según el viajero irlandés John Talbot Dillon, la dieta del oso hormiguero venido de Buenos Aires, en lugar de constar de hormigas y otros insectos, era de 4 o 5 libras de carne picada en pedazos pequeños ${ }^{71}$. Con el pasar del tiempo, las dificultades nutricionales deben de haber pesado y el animal sobrevivió sólo 6 meses en España. Un documento fechado el 31 de enero de 1777, dice que "Esta mañana, se encontró muerto, em la Leonera de este Sítio, el oso ormíguero, que enbiáron al Rey"72. Entonces el animal fue llevado al Real Gabinete donde fue empajado por Juan Bautista Bru, "pintor y
65. Cf. Paula De Vos (2009, p.272).

66. Cf. Ana Victoria Mazo Pérez (2006). Este artículo presenta el facsímil de los principales documentos sobre el oso hormiguero de Carlos III disponibles en los archivos españoles.

67. Cf. Félix de Azara (1802b, v.1, p.61-74).

68. AGP, Buen Retiro, Caja 11756/22. Ver Ana Victoria Mazo Pérez (2006, p.282).

69. Cf. Carlos Gómes-Centurión (2009, p.207).

70. Cf. Félix de Azara (1802b, v.1 p.63).

71. Cf. John Talbot Dillon (1781, p.80).

72. AGP, Buen Retiro, Caja 11756/22. Ver Ana Victoria Mazo Pérez (2006, p.293). 
73. Cf. Juan Bautista Bru (1786, v.2, p.35-36).

74. Cf. John Talbot Dillon (1781, entre 80 e 81$)$. primero disector" del museo, para ser expuesto a los visitantes. Años más tarde, el mismo preparador publicó una serie de descripciones ilustradas de animales de la colección del gabinete, entre los cuales está el oso hormiguero, curiosamente llamado de "osa palmera"73.

Además del diseño que acompaña la descripción publicada por Bru, el oso hormiguero fue conocido a través de su representación gráfica. Así que llegó a España, el rey mandó que el animal fuese retratado. La pintura fue ejecutada y hasta hoy permanece expuesta en el Museo de Historia Natural. El naturalista John Dilon ilustró su libro de viajes a España con una imagen que reproducía la pintura del anima $^{74}$. Esta imagen, que representa el oso hormiguero de forma bastante naturalista, circuló por Europa. Copiada y reproducida, se tornó una especie de imagen estándar de los osos hormigueros, superando las representaciones esquemáticas y extrañas, comunes hasta entonces.

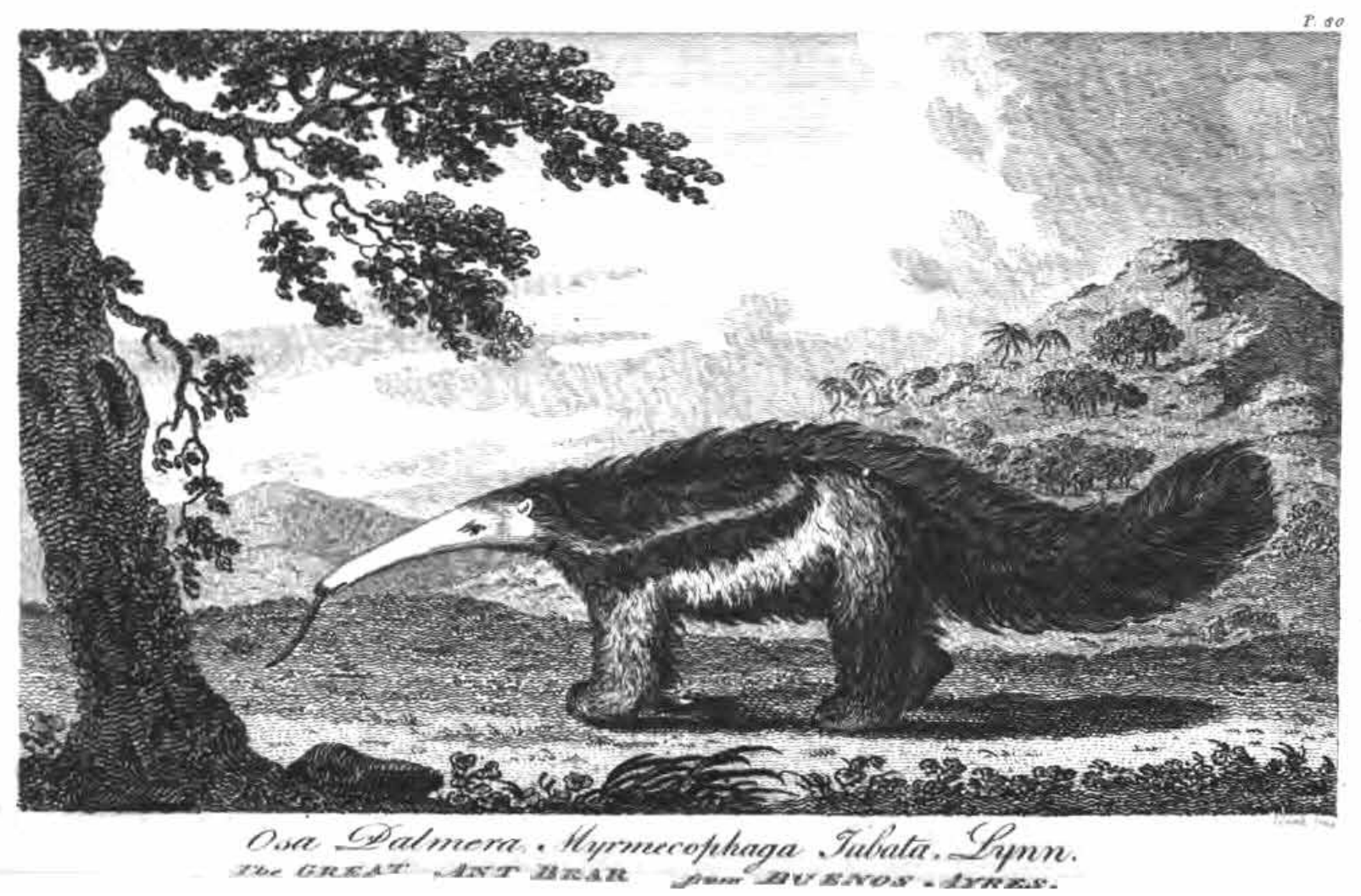

Figura 3 - El oso hormiguero de Carlos III, según John Talbot Dillon

Azara

La balanza entre la impersonalidad científica y los lazos interpersonales de las dádivas sólo pendería para el primer lado cuando el ya mencionado 'zoólogo' Félix Azara pasó a hacer el envío sistemático de productos de la naturaleza 
de la cuenca del río la Plata para España. Es sabido por la historiografía especializada que, en el período la corona española no envió ninguna expedición científica para el Virreinato del Río de la Plata. Mientras Dombey, Ruyz y Pavón viajaban por Perú, Mutis comandaba un equipo de recolección y diseño sistemático de la flora de Nueva Granada y la expedición de Sessé a Nueva España se ramificaba en múltiples brazos en México, Guatemala y California, nadie exploraba la naturaleza del Plata, ratificando la poca importancia de la colonia. Esto, sin embargo, es verdadero sólo en parte. Félix Azara, de alguna manera rellenó este vacío. En la década de 1780, este ingeniero y astrónomo se tornó el principal estudioso de la fauna de la región y fue responsable por la remesa de diversos animales a España, principalmente de aves.

Azara no tenía formación previa en Historia Natural. Sin embargo, se convirtió en uno de los más influyentes investigadores de la fauna sudamericana. El astrónomo fue enviado al Paraguay para integrar la comisión conjunta, responsable por la demarcación de las fronteras entre los territorios portugueses y españoles en América. Por razones estratégicas, Portugal dilató al máximo la ida de sus representantes, haciendo con que Azara permaneciese inactivo. A pedido de Joaquín Alós, gobernador de Paraguay, acabó recibiendo autorización por decreto del 26 de mayo de 1788, para dedicarse al estudio y envío de productos naturales a España, desde que no fuese en detrimento de la demarcación. Debería acompañar al Gobernador...

\begin{abstract}
particularmente cuando salga á la visita, en la cual podrá Vuestra Señoria asociar consigo el capitán de fragata D. Félix de Azara, aprovechándose de su inteligencia em materias físicas, bien entendido que esto sea sin periuicio de su encargo de división de límites y solamente en los ratos y vacantes que éste le permita. Y será conveniente extender las observaciones á todos los tres reino de la naturaleza, sobre geografía fisica y civil, y aun sobre la población, variedad de naciones de indios, su número, costumbles, usos y demás cosas conducentes al progreso de las ciencias y á la economia politica. También se ha complacido S. M. Con el ofrecimiento que hace V. E. De remitir las raras petrificaciones que expresa y la estimable colección de pájaros, por lo comúm desconocidos en Europa, con su puntual descripción, mandándone dar á V. E. Gracias por ello y encargarle se las dé á dicho capitán Azara ${ }^{75}$.
\end{abstract}

Como los integrantes portugueses de la comisión tardaban, Azara pudo dedicarse casi en tiempo integral a los nuevos encargos encomendados por la corona, supliendo el vacio de conocimiento de la Historia Natural de la región. Sin embargo, hubo ciertas peculiaridades en su actuación. A diferencia de las otras expediciones científicas españolas de la época, donde el foco estaba en el mundo de las plantas, Azara se dedicó casi exclusivamente a la fauna. Como consecuencia, se asoció de manera privilegiada con el Real Gabinete, mientras los naturalistas de las expediciones quedaron bajo supervisión del botánico Casimiro Gómez Ortega, director del Real Jardín Botánico.

Para Félix Azara, el foco en la zoología se iba demostrar una gran ventaja. No podemos olvidar que Linneo había desarrollado mucho más su sistema
75. AGI, Indiferente General, legajo 1544, doc. 227. 
76. Ver Alvarro Mones y Miguel A. Klappenbach (1997, p.33).

77. Apud Francisco de las Barras de Aragón (1915, p.363).

78. AGN, Sala 9, legajo 521, 8-1-15.

79. Cf. Félix de Azara (1802).

80. AGN, Sala 9, legajo 521, 8-1-15.

81. Cf. Pedro Franco Dávila (1776, p.100).

82. Apud Francisco de las Barras de Aragón (1915, p.364). taxonómico de clasificación para la flora que para la fauna y para los minerales. En ese momento, la botánica era una ciencia mucho más consolidada que sus asociadas: la zoología y la mineralogía. Las expediciones botánicas del periodo contribuyeron mucho más en el enriquecimiento del tesoro acumulado por esa ciencia, que en su conformación.

Para el estudio de los animales, más que a Linneo, se recurría a Buffon: a los 12 volúmenes de la Historie des animaux quadruèdes (1753-1767) y a los 9 volúmenes de la Historie des oiseaux (1770-1783). En estos estudios predominaban todavía las descripciones de las características más exteriores de los animales, acompañadas de cierto anecdotario sobre ellos. Esto sólo iría mudar a partir de los últimos años del siglo XVIII, cuando Cuvier y otros zoólogos comenzaron a desarrollar la Anatomía Comparada y a establecer las bases de la Paleontología. De este modo, las obras resultantes de la permanencia de Azara en América del Sur, publicadas en español a principios de siglo XIX, tuvieron tiempo de provocar algún impacto en ese que fue el momento constitutivo de la zoología moderna.

No es fácil conocer exactamente el número y la extensión de las remesas de pájaros de Azara, pero se estima que fueron más de $400^{76}$. La documentación permite que se acompañe el proceso, aunque sea parcialmente. En correspondencia al Marqués de Sonora, en julio de 1788, el estudioso comunica haber enviado, a través del Virrey del Río de la Plata, el Marqués de Loreto, "84 aves sumergidas en aguardiente" junto con las descripciones de ellas. Además, decía haber descrito "244 especies de pájaros com bastantes quadrupedos"77. La correspondencia del mismo virrey, del 30 de septiembre de 1789, menciona la remesa de "190 avecillas de 153 especies que ha regogido en la Provincia de Paraguay el capitan de Navio Sn Félix de Azara". También está registrado que se "remete en dos tomos la descripción de las Aves de la Provincia del Paraguay"78. Estas descripciones fueron más tarde ampliadas y perfeccionadas por Azara dando origen a los 3 volúmenes de los Apuntamentos para la Historia Natural de los Páxaros, publicados en $1802^{79}$. Otra gran remesa del naturalista sería hecha 6 años después, cuando fueron enviadas desde Buenos Aires "dos Botijas acomodadas en caxones con 126 aves recogidas en la Provincia del Paraguay" 80 .

Azara también se dedicó al estudio de los mamíferos, pero las remesas de estos animales fueron mucho menos sustantivas. El primer animal de la lista de Dávila, de los "animales apetecidos para el Real Gabinete", era un marsupial americano: la fara (Didelphis marsupiales), la zarigüeya más común en la región andina de origen del director del gabinete ${ }^{81}$. Por lo tanto, no se puede extrañar que junto a su primera remesa de pájaros, el naturalista tuviese enviado una zarigüeya. La correspondencia del Marqués de Loreto dice que, venidos del Paraguay, habían llegado a Buenos Ayres "86 pajarillos de 61 especies y um cuadrúpedo nombrado Muycure, tercera especie. Aquéllos en uma botija, envueltos y separados em lienzos, y éste en un tarro de hoja de lata, conservados todos em aguardiente" "82. Antes de despachar la remesa a España, el Virrey se dio al trabajo de mandar "renovarles el aguardiente para asegurar más su conservación, habiendo hecho antes trasladar el 
cuadrúpedo á um frasco de vidrio por hallarse deteriorado com la humedad el tarro que lo contenia"83.

Azara incluía los marsupiales americanos en la familia de los Fecundos, subdividiéndolos en Micurés, Lanudos y Coligruesos ${ }^{84}$. El espécimen enviado a España era un Lanudo. Más tarde, Azara dijo textualmente que "Le describí quando no tenia los conocimientos que hoy; y metiendole em aguardiente, lo despaché al Real Gabinete de Madrid"85. Se trata de una de las variedades de zarigüeyas lanudas (Caluromys lanatus) y el ejemplar todavía existe en el Museo de Historia Natural de Madrid. Es interesante recordar que el espécimen fue dado a Azara por José García de Francia, que en el futuro sería el principal responsable por la independencia de Paraguay y su dictador: El Supremo.

Otros animales que siempre habían atraído la curiosidad de los naturalistas europeos fueron los endentados sudamericanos. Al enumerar los animales deseados para el Real Gabinete, Franco Dávila recordó...

De los quadrupedo con conchas, llamados Armadillos en unas partes de las Indias, y en otros Quiriquinchos, hai muchas especies que se distinguen por las mas ó menos faxas que tienen encima del cuerpo, como tambien por sus cabezas, asimilandose en unos á la de um puerco, y en otros á la de un perro8.

Él todavía estaba escribiendo su Instrucción, cuando recibió los primeros armadillos. En 1774, el Auditor de Guerra de Buenos Aires ${ }^{87}$ mandó al Real Gabinete, a través de una larga cadena de intermediarios, un tatú bolita (quirquincho). La documentación consultada no permite vislumbrar si se trataba de un ejemplar vivo o muerto. El auditor promete enviar otro armadillo por el correo marítimo y que "fican encargados los quinquichos bola del Paraguay" 88.

Mucho años más tarde, Azara parece haber asumido el encargo y fue responsable, aunque indirectamente, por el envío de diversos armadillos a España. Él dio al virrey un tatú carreta empajado (Priodontes maximus) y también algunos ejemplares aún vivos de tatú mulita (Dasypus hybridus), de mataco o tatú bolita (Tolypeutes matacus) y de pichi, wichí o cabasú grande (Cabassous tatouay). D. Pedro de Melo Portugal los habría enviado a Manuel Godoy, Príncipe de la Paz. El ejemplar empajado acabó en la colección del Real Gabinete, donde permanece hasta hoy ${ }^{89}$. De los restantes, no fue posible conocer el destino. Si llegaron vivos a Europa, deben haber sido encaminados al Retiro o a Aranjuez.

Estando después en Buenos Ayres llegó del Paraguay al Arcediano Don Josef Román Cabezales un Tatú de esta especie. Le habían sacado en una pieza el vestido, y curtido como suela de zapato, cuyo color había tomado en todas partes perdiendo el natural. Le habían rellenado con violencia de yerba del Paraguay; de modo, que la cabeza parecía más plana y corta de lo que es; y el hocico desfigurado, como las cuatro piernas y cuerpo por demasiado abultados. No me pareció lo mismo de la cola, cuyo grueso disminuirían con la costura lo que la violentaron al estirarla. El citado Arcediano me lo dio, y lo regalé á Don Pedro Melo de Portugal con algunas Mulitas, Pichiís y Matacos vivos, que envió al Señor Príncipe de la Paz ${ }^{90}$.
83. Ídem.

84. Cf. Félix de Azara (1802b, v.1, p.209).

85. Idem, p.221.

86. Cf. Pedro Franco d'Ávila (1776, p.122).

87. Muy probablemente D. Juan Manuel de Lavardén.

88. RGHN, doc. 204.

89. Ver Angel Cabrera (1912, p.31-32).

90. Cf. Félix de Azara (1802b, v.1, p.221). 
91. Cf. Angel Cabrera (1912, p.32).

92. Sobre la cultura del valimiento, privanza y favoritismo en el Antiguo Régimen, ver, Ricardo de Oliveira (2005).

93. Apud Carlos Gómez-Centurión (2009, p. 186).

94. AGN, Sala 9, legajo 2154, 24-10-15.

95. AGN, Sala 9, legajo 2166, 25-1-6.

96. AGI, Indiferente General, legajo 1550. Apud Carlos Gómez Centurión (2009, p.204).
Estas remesas de armadillos también permiten que se tenga una noción de la extensión de las cadenas de dádivas, de las cuales los especímenes científicos participaban. Observando las remesas en que Azara estuvo envuelto, es posible acompañar algunas de esas cadenas. Francia da una zarigüeya a Azara, que la remete a Buenos Aires, donde el Marqués de Loreto acrecienta cuidados, de modo a hacerse copartícipe de la dádiva, y la envía al Secretario de Indias. Sólo entonces, el espécimen llega al Real Gabinete. Según Cabrera, la documentación del Gabinete no indica que el ejemplar había venido "de manos de Azara llo que acaso intencionadamente, por dar más valor á su obsequio, calló D. Pedro Melo de Portugal)"91.

Del mismo modo, alguien envía un armadillo empajado al Arcediano de Buenos Aires, que lo da a Azara, que lo regaló al Virrey Melo Portugal, que lo envía a Godoy, valido de Carlos IV y, a la sazón, la figura más poderosa de la administración española92. Pedro Melo de Portugal murió en el ejercicio del cargo. Sin embargo, dejó instrucciones para que sus animales favoritos fuesen enviados a España: "dos pájaros singulares" como regalo para los reyes y un "monito de cabeza blanca" para Godoy, "en memoria del afecto y respeto que conservó hasta el último momento de su vida"93. Centurión-Gómez llamó a esto de obsequio desinteresado. Diríamos, sin embargo, que esas cadenas de dádivas superaban el tiempo de vida de los directamente involucrados y era normal que sus herederos diesen continuidad a ellas. Regalos post morten al rey y a su valido, dados por un hombre arruinado, no eran sólo gestos graciosos.

Los Ñandúes

Como hemos visto en el caso del grifo, del potu, del oso hormiguero, o de algunos armadillos, las remesas de animales a España no se limitaban al caso institucionalizado de Azara. Los envíos 'desinteresados' se alternaban con pedidos específicos de una u otra especie. En 1774 llegó una correspondencia al Virrey, firmada por Julián de Arriaga y Ribera, ministro de la Marina y de las Indias y director de la Casa de Contratación de Cádiz, solicitando que fuese enviado a España un número moderado de pelícanos ${ }^{94}$. En 1783 , fue la vez de su sucesor en el Ministerio de las Indias, José de Gálvez, ordenar al Virrey que fuesen enviados avestruces americanos (Rhea americana). En este caso, el propósito era verificar si las plumas de esto animal podrían reemplazar aquellas de los avestruces africanos en la fabricación de ornamentos. Por sugerencia del Conde de Guara "ha entendido el Rey la grande abundancia de estos Animales que hay em América, y con particularidad en Buenos Ayres, ha excisado à S. M. el deseo si la Pluma de estos puede ser a proposito para aquel uso"95. En el año siguiente, el marqués de Loreto envió una primera partida de 6 ñandúes a Cádiz. Gálvez, sin embargo, no ponía fe en la supervivencia de los animales y, aparentemente, desacreditaba de la utilidad de esta acción ${ }^{96}$.

A principios de 1785, José Martínez, sargento encargado de la Casa de Reclusión Femenina de Buenos Aires, comunicó al Virrey la llegada de una 
remesa compuesta por "trece chínas venidas del Rio Negro" y "once avestruces chicos inclusos los que ha mandado al fuerte, y quedam a su cargo nueve" 97 . Las aves se destinaban al uso científico, mientras las indias permanecían a disposición de las familias bonaerenses interesadas en ellas como empleadas domésticas. La documentación no proporciona elementos para que sepamos con certeza si y cuando estas aves fueron enviadas a Europa, pero es muy probable que hayan seguido para el Retiro ${ }^{98}$.

Alpacas, Guanacos, Llamas e Vicuñas

Los animales más insistentemente solicitados a los Gobernadores de Buenos Aires, y después a los Virreyes, fueron los camélidos sudamericanos. Inicialmente, la corona se ocupó principalmente en llevar vicuñas (Vicugna vicugna) a España. En 1756, ya existía uno de estos animales viviendo en el Retiro99 y fue también en este exacto año que Georges Louis Leclerc, el futuro Conde de Buffon, publicó una frase que se haría obligatoria siempre que estos animales eran mencionados: "Je imagine que les vigognes seroient une excellente acquisition pour l'Europe et produiraient plus de biens réels que tout le métal du Nouveau Monde" 100 .

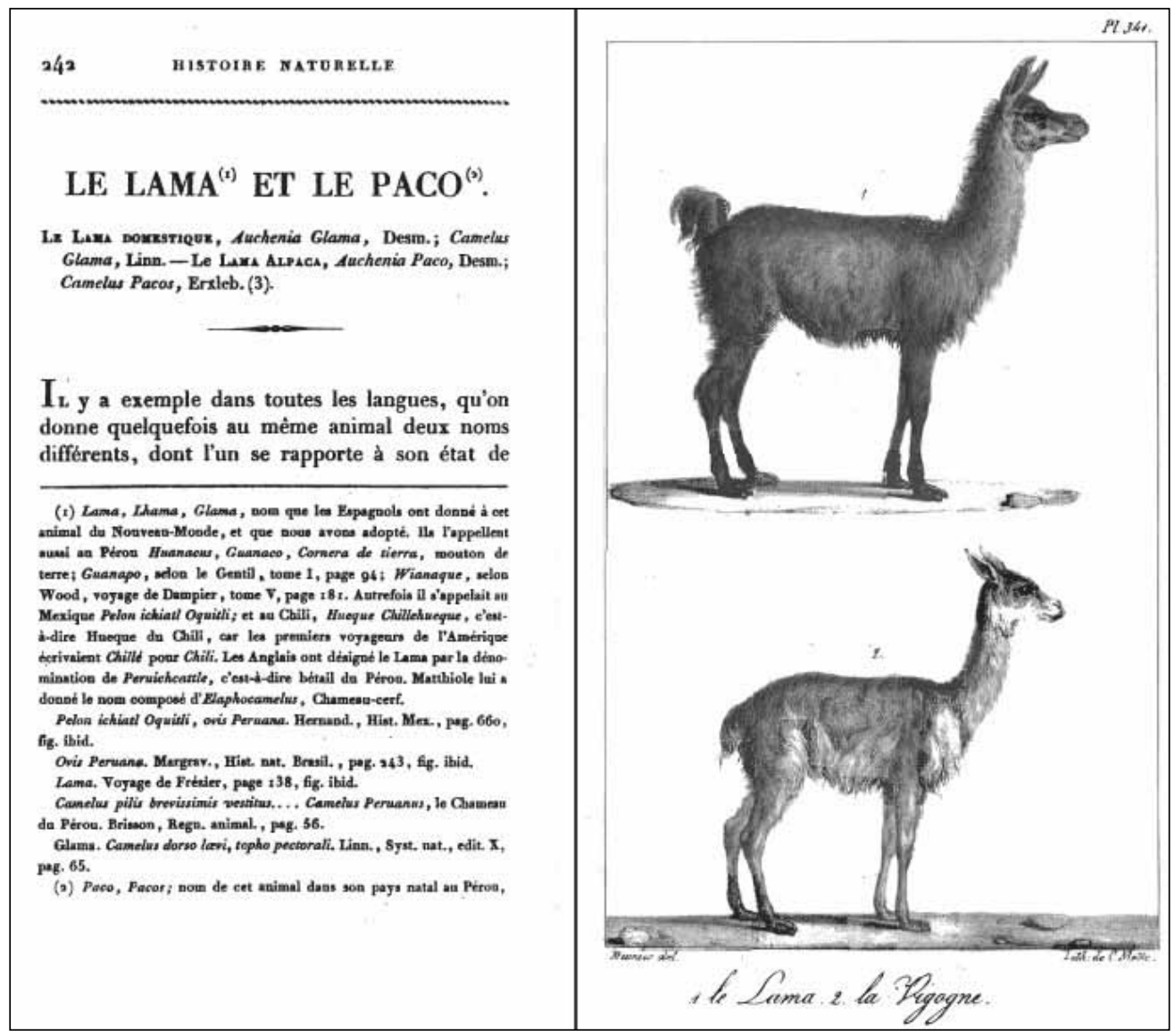

97. AGN, Sala 9, legajo $1840,21-2-5$.

98. Ver Helen Cowie (2011, p.16).

99. AGP, Buen Retiro, $11752 / 15$.

100. Cf. Georges Louis [Buffon] Leclerc (1765, v.13, p.32).
Figura 4 - Camélidos sudamericanos en la Histoire Naturelle de Buffon 
101. Cf. Montesquieu (1941, t.2. p.10 y ss). El filósofo escribió sus Considérations sur les richesses de l'Espgne (1727) y aún más después de publicar De l'Esprit des Lois (1748) la explotación de metales preciosos pasó a ser satanizada por diversos tratadistas.

102. Cf. Agustín González Enciso (1980, p. 575-576).

103. AGN, Sala 9, legajo 2152, 24-10-13.

104. AGI, Lima, 651/59 y 652/ 182. AGP, Casa de Campo, 9 y 10. Apud Carlos Gómes-Centurión (2009, p.201).

105. Cf. Calors Gómes-Centurión (2009, p.203).
La idea de que las vicuñas traerían mucho más beneficios a Europa que toda la plata y el oro traídos del Nuevo Mundo muestra cómo eran comunes las teorías de Montesquieu, según las cuales los metales preciosos habían sido responsables por la decadencia de Portugal y España ${ }^{101}$. Toda la repercusión y poder de afirmación de Buffon se puede sentir en la actuación posterior de las autoridades españolas. Las vicuñas, que hasta entonces eran un asunto de economía colonial, se convirtieron en cuestión estratégica metropolitana. La lana de estos animales, que se mantenían en estado salvaje, igual que en América, era muy apreciada porque su calidad era considerada superior a la de los carneros. Los indígenas cazaban y mataban grandes cantidades de vicuñas para tomar su lana, que era utilizada en sus trajes y parte vendida para los españoles. A finales de 1760 fueron hechas tentativas de producir tejidos de alta calidad, con la lana de vicuña y de guanaco, en la Real Fábrica de Guadalajara ${ }^{102}$. Como parte del proceso, la corona dio inicio a una tentativa de aclimatación y domesticación de estos animales en España. A los virreyes de Perú y del Río de la Plata se ordenó que, siempre que fuese posible, enviasen ejemplares a España.

A principios de 1768, el secretario Julián de Arriaga solicitó al gobernador de Buenos Aires que se enviasen, entre machos y hembras, 12 vicuñas a España. En julio del mismo año, el ministro mandó instrucciones precisas sobre los cuidados a tener con los animales, considerando que eran nativos de los climas fríos de los Andes.

Que las vicuñas se crien desde un mes despues de nacidas en Pueblo situado en temperamento calido, y con comestibles caseros hasta el tiempo de embarcarlos (que este debe ser lo menos á la edad de un año) para preparar su naturaleza al aguante de los calores que se experimentan en la navegación dentro de los Trópicos ${ }^{103}$.

Deberían, todavía, ser habituadas a comer ración seca, ante la imposibilidad de llevar en los navíos la "yerba fría" a que estaban acostumbradas. Por último, si durante la travesía alguna de las vicuñas muriese en las proximidades del Ecuador, debido al excesivo calor, las demás deberían ser esquiladas, pero con el cuidado de no acercarse demasiado del coro. El mismo tipo de instrucciones fue enviado al Virrey del Perú Manuel Amat, el cual sin embargo seguía la opinión de que los animales no podrían sobrevivir el viaje "por su natural temperamento inavenible con el calor de la zona tórrida"104. No obstante mandó algunos ejemplares a España, que de hecho no sobrevivieron. En cuanto al Virreinato de la Plata, la documentación es demasiado fragmentaria para que se pueda saber si las órdenes fueron cumplidas y si algunas vicuñas llegaron a ser enviadas a Europa en este período. En la década de 1790, una remesa de 12 de esos animales fue enviada desde Perú. Sólo uno de ellos sobrevivió y era mantenido en el Retiro como curiosidad zoológica ${ }^{105}$.

Las tentativas fracasadas de aclimatación de vicuñas en este período hicieron con que Centurión-Gómez afirmase que "después de innumerables descalabros, es posible detectar ya un considerable cansancio entre las autoridades 
españolas frente a esta clase de empresas, condenadas desde el principio al fracaso pese a que tanto entusiasmaban a Carlos $1 \|^{\prime \prime 106}$. Sin embargo, no es lo que se observa en la documentación del Virreinato de la Plata. Exactamente en esta época se iniciaron las tentativas de aclimatación de guanacos (Lama guanicoe), que fueron más duraderas y persistentes que las de vicuñas. En los reales establos de Aranjuez, como hemos visto, eran criados diversos animales regalados a Carlos III: una cebra de Brasil, una vaca enana y un buey que amamantaba un ternero. En 1778, tal mirabilia semoviente fue enriquecida con guanacos traídos de las colonias sudamericanas $^{107}$. El Barón de Bourgoing, embajador de Francia, vio dos de ellos a pastar y a saltar como si las campiñas de Aranjuez fuesen su país natal ${ }^{108}$. La presencia de estos animales, que sobraron de alguna remesa sin éxito, marca el inicio de la segunda fase del proceso de importación y aclimatación de camélidos sudamericanos, que se había concentrado en los guanacos.

Lejos de cualquier desánimo, lo que se percibe es que fueron hechos enormes esfuerzos para llevar y aclimatar estos animales a Europa. Ni siquiera las guerras en que España estuvo envuelta, a finales del siglo XVIII e inicios del XIX, fueron motivos suficientes para impedir el transporte de guanacos a la Península. Durante la guerra de Independencia de América del Norte, en la cual las coronas borbónicas de Francia y de España apoyaron a los colonos insurgentes contra Inglaterra, los vasos militares españoles continuaban a transportar estos animales. En correspondencia de octubre de 1782, el Marqués de Sonora determinó al Virrey de la Plata que fuesen enviadas remesas de 4 a 6 hembras de guanacos en los navíos de guerra o mercantes, con el objetivo de procrear con los que estaban en España. En Aranjuez ya había 5 machos, enviados anteriormente, y que "se mantienem muy hermosos", afirmaba Sonora. Cuando terminase la guerra, las remesas enviadas deberían ser mayores, incluyendo nuevos machos ${ }^{109}$. Después de haber firmado el Tratado de Versalles, en 1783, el Marqués de Sonora y el Virrey Loreto condujeron un proceso sistemático de envío de guanacos para la Península Ibérica. El proceso suplantó la noción hasta entonces dominante, la de remesas de dádivas, para inscribirse en un proyecto de aclimatación, desarrollado en sintonía con las más modernas tendencias europeas, que agregaban conocimiento científico y utilitarismo económico. Las dificultades enfrentadas eran inmensas. En correspondencia del 16 de julio de 1785, Sonora avisa a Loreto que ya habían fallecido todos los guanacos hasta entonces enviados y que deberían ser enviados nuevos grupos de hembras y algunos machos ${ }^{110}$. Como resultado, el Virrey respondió que pretendía ahora pasar a prepararlos previamente, antes de la travesía del Atlántico. Retomó la antigua idea de traer crías de las provincias de Salta y Córdoba y criarlos en las estancias de Buenos Aires, para enseñarlos a comer cereales (granos) y ración (afrecho) ${ }^{111}$. Otra tentativa fue la de preparar los guanacos para un largo viaje de travesía en la Casa de Reclusión Femenina de Buenos Aires, a los cuidados de las indias, tal como se hizo con los ñandúes.

En consecuencia del proyecto, treinta guanacos fueron trasladados a Montevideo, para que de allí fuesen remitidos a España, en 1785112. Otra partida
106. Idem, p.203.

107. Cf. Juan Antonio Alvares de Quindos y Baena (1804, p.334).

108. Cf. J.F. Bourgoing (1797, v.3, p.68).

109. AGN, Sala 9, legajo 2165, 25-1-5.

110. AGN, Sala 9, legajo 2206.

111. AGN, Sala 9, legajo 523, 8-1-17.

112. AGN, Sala 9, legajo 527, 8-2-4. 
113. AGN, Sala 9, legajo 527, 8-2-4.

114. AGN, Sala 9, legajo 1840, 21-2-5.

115. Cf. Tadeo Ortiz de Ayala (1822, p.42).

116. RJB, 01/0012/003/0010.

117. AGN, Sala 9, legajo 2189, 25-2-14. de guanacos llegaría a Buenos Aires, en enero de 1788, enviada por el gobernador de Córdoba ${ }^{113}$. No menos que 31 animales fueron entonces remitidos a España, a través de Montevideo. Junto con la carga viva, fueron embarcados los víveres para el viaje, compuestos de "cien fanegas de cevada, Mayz, y arina delo mismo, todo acomodado en ochenta, y cuatro sacos, con mas tres sacos con 4 fanegas, y media delo mismo e 3 p.s de pasto pa el viaje de Montevideo"114.

Hay información de que, en 1786, Teodoro de Croix, Virrey del Perú, envió una partida de 100 guanacos a México ${ }^{115}$. La idea era establecer una chacra para cría en Nueva España y de allí abastecer a España. El número de animales parece sobrevalorado, pero de todos modos ellos no sobrevivieron.

Como se ha percibido, la década de 1780 fue el pico de envío de animales a España desde el Virreinato del Río de la Plata. La remesa de especímenes exóticos solitarios fue sustituida por la de grandes cantidades de guanacos, con miras a su reproducción en Europa. A continuación, estos animales desaparecieron de la documentación referente al Virreinato para retornar en una coyuntura un tanto diferente.

Carlos III fue sucedido por su hijo, Carlos IV, y España se veía cada vez más envuelta en la órbita francesa, primero en la de la monarquía borbónica y después, pasada la fase más aguda de la revolución, en la de Napoleón. Cada vez más el comando sobre España se concentraba en las manos de la figura toda poderosa de Manuel Godoy. El Príncipe de la Paz, entre otras cosas, había sido nombrado por el rey protector de la Real Academia de Nobles Artes, y de los Reales Gabinetes de Historia Natural, Jardín Botánico, Laboratorio Químico y Observatorio Astronómico. Es decir, la política científica española pasó a su órbita. El valido del rey usaba de su posición privilegiada en el control de las instituciones científicas para mantenerse en las buenas gracias de Napoleón. A través de Godoy, Josefina de Beauharnais hizo uso de la red española de recolección de plantas y animales para abastecer Malmaison.

Como ya hemos dicho, la Emperatriz de los franceses era una vehemente adepta de la aclimatación. A través de sus contactos con la reina María Luisa de España y con Godoy, la Emperatriz Josefina obtuvo la autorización de Carlos IV, en 1802, para que le fuesen enviados ejemplares botánicos venidos de las colonias americanas $^{116}$. En los jardines de Malmaison vivían sueltos diversos animales exóticos, de canguros a gamos, pasando por cebras y avestruces. Josefina era admiradora de la obra de Buffon, lo que le llevó a mantener viva la idea de que las vicuñas producirían más riquezas para Europa que todo el oro traído de América. No es de extrañar, por lo tanto, que ella haya tomado como suya la tarea de promover la aclimatación de los camélidos sudamericanos en Francia.

A través de una Real Orden, fechada el 10 de febrero de 1804, la corona determinó al Virrey del Perú que providenciase el envío de grupos de estos animales a Buenos Aires, para de allí seguir a Europa, para servir de regalos a Josefina ${ }^{17}$. La misma orden determinaba también a todos los Gobernadores, 
Intendentes y Subdelegados de las provincias del Virreinato de la Plata, que remitiesen ejemplares de estos animales a la capital.

A finales de 1805, ni los animales de Perú habían llegado, ni los gobernadores de las provincias habían tomado las providencias solicitadas. La omisión resultó en reprimendas generalizadas, venidas de España, y en órdenes perentorias al Virrey.

En vista de todo ha resulto S. M. que V. E. no perdone gasto ni omita diligencia ó medio alguna para conservación y pronto envio de las Alpacas, Guanacos, Llamas y Vicuñas a fin de proporcionar a la Reyna N. Sa la complacencia de satisfacer en esta parte los deseos de la Emperatriz Josephina ${ }^{118}$.

La correspondencia fue firmada por Miguel Soler, Ministro de la Hacienda del gobierno dirigido por Godoy, fechada el 5 de diciembre de 1805, es decir, poco más de 2 meses después de la batalla de Trafalgar, en la cual España perdiera su marina, y con ella la condición de continuar a ser una potencia colonial. Los camélidos no sólo no fueron enviados, como Buenos Aires quedó a merced de los ingleses, que por dos veces invadieron la ciudad.

La cuestión de las llamas y de las vicuñas sólo volvió al primer plano en los años 1808 y 1809, momentos finales de la colonización española en la Plata. Para que se perciba la importancia atribuida a la cuestión, hay que tener en cuenta que, en el exacto momento de las independencias, los dirigentes metropolitanos y coloniales todavía se preocupaban con los animales solicitados por Josefina. En 1809, aún estaban siendo expedidas órdenes al Virreinato de la Plata para que fuesen enviados camélidos a España, y que fuesen escritas memorias sobre la criación de estos animales ${ }^{119}$. El 9 de diciembre de 1809, finalmente desembarcó en Sevilla, venido de Buenos Aires, un rebaño mixto de guanacos, llamas, vicuñas y alpacas. Llegaban, finalmente, las llamas de Josefina, pero la alianza francoespañola ya se había deshecho y los animales permanecerían en España.

\section{El Megaterio}

Como hemos visto en el caso de los guanacos, Nicolás del Campo, el Marqués de Loreto, fue uno de los virreyes de Buenos Aires más activos en el envío de productos de historia natural a España. Era de su responsabilidad el envío al Real Gabinete, en 1787, de un hallazgo que vendría a tener fuerte impacto en la conformación de la paleontología y de la zoología modernas. Se trataba de una osamenta de un ser enorme, que estaba destinado a reavivar antiguas controversias. En los medios académicos españoles, y también en el resto de Europa, todavía se discutía si estos enormes huesos, periódicamente desenterrados, pertenecían a gigantes bíblicos ${ }^{120}$.

Este no fue el primero, y estaba lejos de ser el último hallazgo paleontológico hecho en la región. Hay diversas referencias documentales más antiguas acerca del encuentro de este tipo de osamentas. El caso más conocido es el del jesuita inglés
118. AGN, Sala 9, legajo 2190, 25-2-15.

119. AGN, Sala 9, legajo 2257, 25-5-13.

120. Ver Francisco Pelayo (1994, v.3, p.161-182). 
121. Cf. Thomas Falkner (1774, p. 55).

122. Cf. Guillermo Furlong (1948, p.334-338).

123. Cf. Francisco Pelayo (1994, p.178).

124. Sobre el descubrimiento y el envío del megaterio, la principal fuente sigue siendo Guillermo Furlong (1948, p.338-350).
Thomas Falkner, que en sus viajes se deparó con los restos de una criatura intrigante: "I myself found the shell of an animal composed of little hexagonal bones each bone an inch in diameter at least and the shell was near three yards"121.

Se trataba del animal extinto que hoy es conocido por gliptodonte (Glyptodon clavipes). El sacerdote también mencionó que otros jesuitas habían encontrado el esqueleto completo de un "yacaré monstruoso". Sin embargo, no se sabe el destino dado a tales osamentas, pero es poco probable que hayan sido enviadas a Europa y aún menos probable, a España.

Antes del descubrimiento del esqueleto del megaterio hubo también el conocido caso de los hallazgos paleontológicos del capitán de fragata Esteban Álvarez del Fierro. A principios de 1766, el militar pidió permiso para exhumar las osamentas de dos 'sepulcros', con huesos gigantes, situados cerca del río Arrecifes. Los 'restos mortales' fueron llevados a Buenos Aires y examinados por expertos, que no llegaron a un consenso si era de "racional", de gigantes, o de otro ser conocido ${ }^{122}$. Fierro, aparentemente, llevó la osamenta para Madrid, donde la tendrían examinado en la Real Academia de Historia. Los peritos en anatomía concordaron que no era humano, pero pertenecía a algún cuadrúpedo desconocido ${ }^{123}$.

Así, la descubierta de los restos del animal que se denominaría de megaterio se insertaba en una larga cadena de hallazgos fósiles ${ }^{124}$. En 1787, el alcalde de la villa de Lujan, Francisco Aparicio, y el fraile dominico Manuel Torres, iniciaron la excavación del gran esqueleto hallado en las orillas del río que daba nombre al lugar. El religioso se encargó de comunicar el hecho y pedir ayuda al Virrey de Loreto, iniciando una sociedad entre ellos. Torres era una figura cuidadosa y demostró gran afición para la excavación 'paleontológica'. Muchos huesos estaban se deshaciendo. Las excavaciones fueron hechas poco a poco y la idea era que los huesos secasen y endureciesen antes de retirados. Finalmente, cuando los huesos ya estaban expuestos, el religioso pidió al Virrey un diseñador que hiciese diseños in situ, con el fin de asegurar el conocimiento de la posición relativa de los huesos. Loreto mandó un militar a Luján para ejecutar la tarea. El esqueleto, prácticamente completo, fue enviado a Buenos Aires. Allí, bajo los cuidados de Loreto, él fue nuevamente diseñado y embalado en 7 cajones. El responsable por este diseño fue José Custódio de Sá Faria. Este militar, como es sabido, fue encargado de proteger el sur de Brasil, en la invasión española de 1777. Fue completamente derrotado y con miedo de ser castigado desertó al bando español. Cuando los invasores se retiraron, Sá Faria los acompañó y pasó a trabajar en Buenos Aires para la corona española.

A finales de 1787, la remesa ya estaba preparada para ser enviada a España. Nicolás del Campo, el Marqués de Loreto, tenía plena conciencia del valor científico del hallazgo y se cercó de los mayores cuidados. Las piezas fueron rotuladas, numeradas y embaladas en paja. El Virrey no mandó la osamenta directamente al Real Gabinete pero a Antonio Porlier, el Secretario de las Indias. De 
esta forma, Loreto tomó las debidas precauciones para que fuesen atribuidos a él los méritos de este hallazgo científico.

Cuando la remesa finalmente llegó al Real Gabinete, causó gran excitación. Porlier, parece no haber aceptado la idea de que se trataba de un animal extinto. En la época, esta noción era aún controversia. No satisfecho, ordena a Nicolás del Campo que "procure por quantos medios sean posibles averiguar si en algún partido de Luján, o en otro de los de ese Virreinato, se puede conseguir algún animal vivo, aunque sea pequeño, de la especie de dicho esqueleto, remetiéndolo vivo, si pudiese ser" ${ }^{\prime 25}$. En una tentativa de atender al pedido, Loreto convocó indios patagónicos para observar los huesos y saber si conocían el animal a que pertenecían. Ante la negativa de los indígenas, llegó a la conclusión de que ellos "o extinguieran cuando eram únicos señores de estas tierras"126. Como se observa, es antigua la discusión sobre el papel de la acción humana en la extinción de gran parte de la megafauna americana.

Las petrificaciones eran especialmente apreciadas por Franco Dávila y, en consecuencia, el Real Gabinete ya nació con una importante colección de fósiles, la cual, acrecida de múltiples contribuciones, se convertiría en una de las más importantes de Europa. Una de las salas del museo era dedicada a las petrificaciones y Dávila hizo constar en sus Instrucciones un capítulo específico sobre ellas. "Llamamos petrificaciones diferentes animales o parte de ellos, como peces, conchas, cangrejos, huesos, maderas, hojas de árboles, etc. Que se encuentran debaxo o encima de la tierra, convertidos en piedra"127.

El impacto del hallazgo del megaterio en la zoología y en el desarrollo de la paleontología es bien conocido. La osamenta fue entreguada a los cuidados de Juan Bautista Bru, qu hasta 1793 trabajó en la preparación, descripción y montaje de los huesos. También elaboró una publicación al respecto, reuniendo sus descripciones y diseños. Las chapas de los grabados de ilustraciones fueron abiertas, pero la publicación acabó no aconteciendo. Algunas pruebas de estos grabados llegaron a las manos de Georges Cuvier, que publicó una memoria al respecto, en 1796, sin referirse a Bru ${ }^{128}$. El naturalista francés se apropió conscientemente del trabajo de otros y se adelantó a publicar, pues sabía que las ilustraciones "doivent probablement servir à quelque dissertation dont ce squelette sera l'objet" 129.

En el mismo año, el ingeniero José Garriga, compró las ilustraciones y descripciones elaboradas por Bru, que vivía eternamente en estado de bancarrota. A continuación, las publicó en una especie de reparación científica "á Don Juan Bautista Bru, sino tambén a nuestra Nacion"130. Incluyó en la obra un prólogo de su autoría y la traducción española de las memorias de Cuvier. Las descripciones hechas por Bru son muy interesantes, puesto que él procuró comparar cada hueso descrito, con los correspondientes humanos y de otros grandes animales, como los de elefantes y rinocerontes. Por su vez Cuvier, que acabó con la mayor parte de los laureles, fue responsable por bautizar el animal de meghaterium y por incluirlo en la familia de los perezosos (Bradipus), es decir, más que Bru, el zoólogo francés, transformó los huesos en objeto de ciencia ${ }^{131}$. En una publicación posterior, Cuvier
125. AGN, Sala 9, legajo 2171, 25-1-11.

126. Cf. Guillermo Furlong (1948, p.346).

127. Cf. Pedro Franco d'Ávila (1776, p.123).

128. Toda la secuencia de como el megaterio hace su entrada en los medios científicos europeos puede ser acompañada en José M Lópes Pinhero y Thomas Glick (1993, p.65-71).

129. Cf. Georges Cuvier (1796, p.303).

130. Cf. José Garriga (1796).

131. Cf. Georges (1796, p.305). 
132. Cf. Georges Cuvier (1804).

133. Cf. José Garriga (1796, Prólogo). volvió al tema y dio los debidos créditos, con base en la publicación de Garriga: a Juan Bautista Bru, por su trabajo, y al Marqués de Loreto, por su remesa desde la Plata ${ }^{132}$. El dominico Manuel Torres, responsable por la descubierta y excavación minuciosa, desapareció de esta historia, suplantado por Loreto.

I.Ax, I.

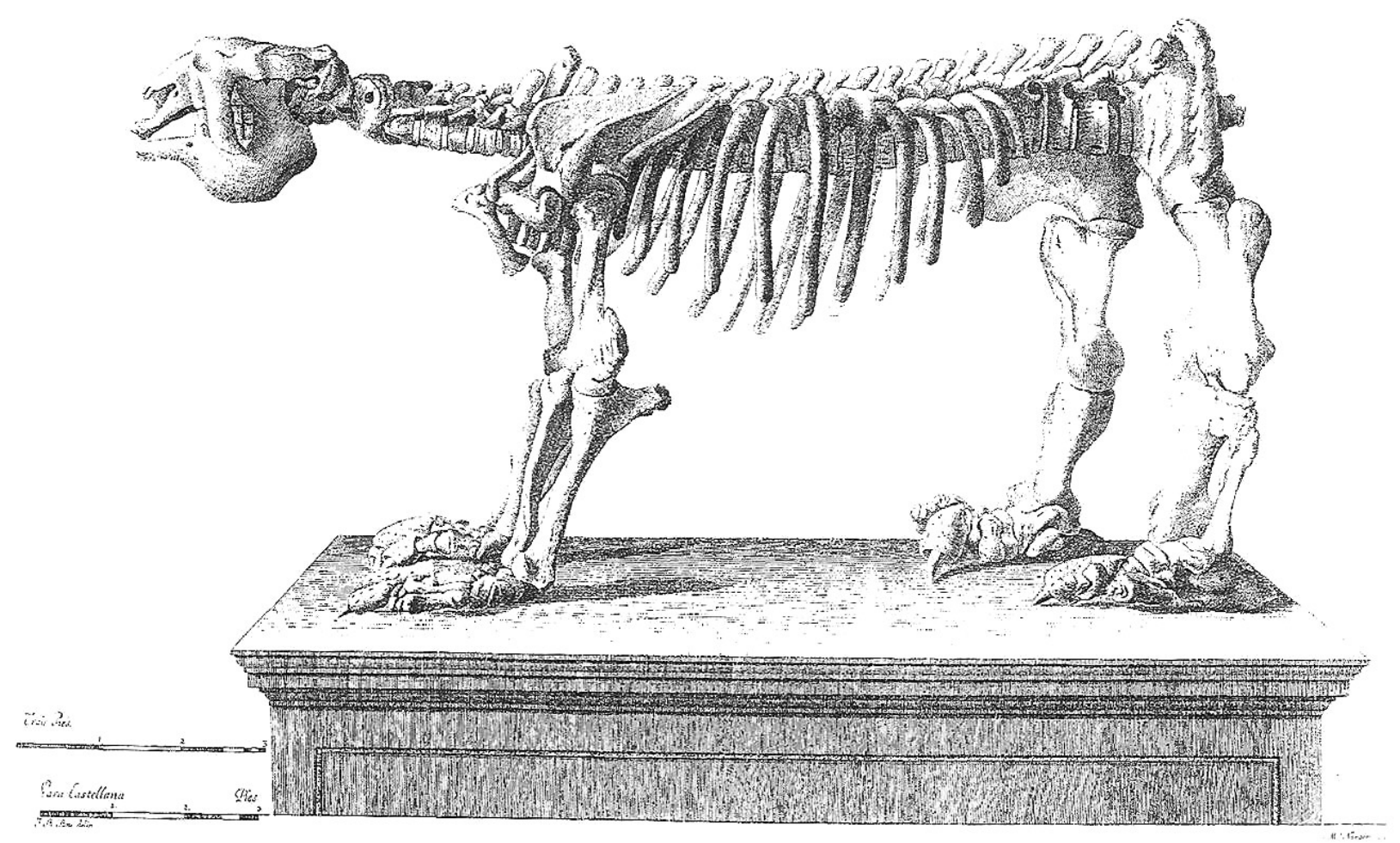

Figura 5 - El megatherium de Lujan, según Juan Bautista Bru

Otras petrificaciones

La inclusión de petrificaciones venidas del Virreinato del Río de la Plata en la colección del Real Gabinete no se detuvo allí. Es interesante percibir que ellas fueron obtenidas a través de las tres formas básicas de funcionamiento de la red de recolección científica española. El propio José Garriga se refiere a otros huesos de megaterio, venidos de Paraguay, que llegaron al museo a través de una larga cadena de donaciones privadas. Una señora de Madrid recibió como regalo, venidos de la colonia, algunos huesos de la cola del animal. Terminó por darlos a un sacerdote. Después de la muerte del sacerdote, su colección de Historia Natural fue incorporada a la del museo estatal ${ }^{133}$. 
Por otro lado, los viajes científicos patrocinados por la corona también produjeron sus frutos. En 1794, José Clavijo y Fajardo, subdirector del Real Gabinete, organizó una expedición mineralógica a América del Sur dirigida por los hermanos Christian y Conrad Hueland ${ }^{134}$. En su estada en el Virreinato del Plata, los naturalistas recogieron y compraron fósiles de la costa patagónica, inmediatamente enviados a España. En la lista de los Hueland aparece:

Pétrification d'un Crustacé, c'est un Crabe amphibie de conservation assez parfaite, dont les interstices de ses articulations sont remplis de matière terrestre sabloneuse-grenve. 6 pouces sur 4 du Port S'Joseph a la Côté Patagone

Osement fossile spongieux et poreux d'un animal amphibie, ainsi disposé et preparé par la nature pour recevoir le suc lapidifique ou les molecules terrestres pour se pétrifier. Cette pièce qui a son mérite, paroitêtre une portion organique de la tête et du col d'un petit crocodile connu en cette Amérique sous les noms de Cayman et de Jácara ${ }^{135}$.

Por último, tenemos la contribución de uno de aquellos funcionarios ilustrados a quien las Reales Ordenes distribuidas por el imperio instaban a mandar productos de la naturaleza para las instituciones científicas metropolitanas. Es el caso de las árboles fósiles mandadas por Joaquín Alós, el Gobernador de Paraguay responsable por transformar la misión de demarcador de fronteras de Félix Azara en una expedición zoológica. Según el propio gobernador, "llevado únicamente del deseo de ser útil al patriotismo y á mis semellantes" él se propuso a

investigar y examinar por mí mimo algunas materias petrificadas, que por lo regular están depositadas en las márgenes de estos ríos [Paraná y Paraguay] con otros muchos tesoros con que la naturaleza ha enrivecido la tierra, y, en efecto, logré sacar del centro de ella y arenal de Paraná con mis proprias manos un árbol petrificado que, a mi entender, parece ser sauce por su configuración ${ }^{136}$.

Las petrificaciones solamente llegaron al Gabinete en 1794, a través del Duque de la Alcudia, es decir, de Godoy, que aún no era Príncipe pero ya era el todo poderoso "ministro universal" de Carlos IV ${ }^{137}$.

Utilidades

Cuando se trata de la ciencia en la Península Ibérica en el siglo XVIII es obligatorio hacer una inflexión explicativa, para superar el topos del "utilitarismo ibérico". Una gran parte de la historiografía contemporánea ha tratado de mostrar que el utilitarismo en las ciencias no era una característica ibérica, sino una marca general del iluminismo. Paula de Vos sintetiza muy bien la situación de esta cuestión. Le pasamos la palabra, por lo tanto:

The utilitarian character of natural history investigation in the eighteenth century-and of Enlightenment pursuits generally-is admittedly not a new concept. Works on French botany in the Paris Academy of Sciences and King's Garden have documented clear evidence of attention to utility and applied science with regard to botanical investigation. The preponderance
134. Cf. Angel Montero y Carmen (1998, p.69-78).

135. MNCN, doc. 667 .

136. AGI, Indiferente General, legajo 1544, doc. 227.

137. RGHN, doc. 171. 
138. Cf. Paula De Vos (2007, p.213). Ver también, entre otros, Robin Briggs (1991); Emma Spary (2000); Richard Harry Drayton (2000); Nuria Valverde Pérez (2007) y Lorelai Kury (2004).

139. Ver Jorge Cañizares-Esguerra (2006, en especial, los capítulos 2 y 3 ).

140. AGN, Sala 9, legajo 2189, 25-2-14. of useful items in Dutch cabinets of curiosity has been widely interpreted as a natural consequence of their capitalist spirit. It is the historians of the British Empire, however, who have tended to dominate the field, establishing clearly the prominence of utility in British Enlightened science, and the gathering of natural history specimens and information with a view toward their applied uses. Similarly, histories of British botanical gardens stress the utilitarian goals of plant cultivation and the idea that increased knowledge would lead to general "improvement" of society. Their detailed evidence and careful argumentation have led to the conclusion that scientific research could indeed take place in the service of empire ${ }^{138}$.

Autores como Cañizares-Esguera van allá. Reafirman el carácter empírico, práctico y utilitario de la tradición científica española, proponiendo, sin embargo, el reconocimiento de estas características bajo el signo de la positividad, una vez que habría sido esta precisa particularidad la responsable por dar las bases a partir de las cuales fueron construidas las ciencias modernas ${ }^{139}$.

Contrariamente a lo que se podría suponer, fueron relativamente raras y ocasionales las solicitaciones de remesas a los gobernantes del río de la Plata que pueden ser vinculadas a una percepción economicista de la red científica. Una primera característica a destacar es que, al contrario de los pedidos genéricos de plantas y semillas, que parecen ser ignorados, los pedidos específicos de materias primas para estudio, si así podemos llamarlos, acostumbraban ser atendidos. Esto contrasta tanto con nuestras expectativas de estudiosos de la historia de las ciencias, como con aquellas de los que en la época estaban involucrados con la práctica científica. La insistencia en la distribución de manuales y circulares, solicitando remesas de ejemplares para coleccionismo y estudio de la naturaleza demuestra esa expectativa. Sin embargo, el predominio de las relaciones interpersonales tornaban más efectivos los pedidos caso a caso, persona a persona. En muchas ocasiones, las solicitaciones de envío de muestras específicas eran hechas para comprobar la validez de la intuición de alguien sobre las posibilidades económicas de algún producto. Ya hemos visto el caso del Conde de Guara, que había sugerido que las plumas de los ñandúes podrían ser utilizadas para uso decorativo, en substitución a aquella de los avestruces africanos. Otro pedido bien característico de esta modalidad ocurrió en 1777, cuando el ministro Gálvez ordenó al Virrey el envío de muestras de "Orchilla de superior calidad que se supone produce la Isla de Falkland", y que fuese estudiada "la posivilidad, y medios de hacer su recolección com moderados gastos", para que el liquen pudiese ser explorado comercialmente ${ }^{140}$. La orchilla (Roccella canariensis) es un liquen del cual se extrae tintes naturales de color púrpura, que durante siglos eran utilizados para teñir tejidos. Su explotación fue una de las bases económicas de la colonización de los archipiélagos portugueses y españoles del Atlántico. Los holandeses estuvieron profundamente involucrados en el comercio de este y de otros tintes de las islas. Así, no es de extrañar que la propuesta de aprovechamiento de la orchilla de las Malvinas haya partido del Vizconde de la Herreria, plenipotenciario español de Haya.

Otras remesas de este tipo fueron hechas sin que la documentación consultada revele el autor del pedido. Es el caso de las muestras de yerba mate (Ílex 
paraguaiensis) y de yerba culén (Psoralea glandulosa), que llegaron al Real Gabinete en 1778, procedentes de Paraguay ${ }^{141}$. También fue enviada, a pedido de las

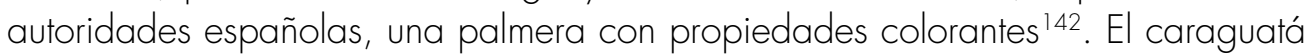
(Bromelia hieronymi, Bromelia balansae y otras) fue otra utilidad vegetal paraguaya que despertó interés en España. Félix Azara ya había llamado la atención para las posibilidades económicas de algunas bromeliáceas que los guaraníes llamaban de "pitas, cardas y caraguaias"143.

\begin{abstract}
Las cortan o arrancan las matas; las pudren como el cáñamo, sacan fácilmente con los dedos la piel, y quedan las hebras tan finas como las del cáñamo y del mismo color, a las que llaman estopa de cuaraguatá. Sin más beneficio las hilan para coser zapatos; y enredándolas un poco con un rastrillo hecho de seis u ocho clavos comunes, calafatean con ellas las embarcaciones con la ventaja, de que nunca aflojan ni se pudren en el agua. No hay duda que pueden hacerse del caraguatá lonas, jarcias y cables, que resistirían más que los de cáñamo, según yo he experimentado en pequeño. Verdad es que presumo no tendrán tanta flexibilidad, y pues no admitirán bien el alquitrán.
\end{abstract}

En 1789, Ilegaron a Madrid cajones procedentes de Paraguay conteniendo "cuatro arrobas y trece libras de Caraguatá o estopa de la tierra"144. Todo indica que estaban siendo hechos testes con esas fibras para la producción de cuerdas. En 1801, el Ministro de la Hacienda, Miguel Soler, comentó que el Virrey Gabriel de Avilés había hecho experimentos de producción de "jarcias y cables". Soler pide entonces al nuevo Virrey, Joaquín del Pino, para continuar las experiencias y mandar muestras para que ellas también fuesen hechas en España. La tarea de hacer "amarras y cables" de caraguatá fue repasada al gobernador de Paraguay ${ }^{145}$.

Las solicitaciones de muestras de maderas formaron un caso individual, una vez que, si bien podamos aprehenderlas como ejemplos del utilitarismo científico, ellas también pertenecían al cuadro más general de la política de recolección botánica. En la serie de instrucciones circulares sobre el envío de plantas, distribuidas por las colonias en la década de 1780, había un énfasis en la solicitud de estas muestras $^{146}$. En este ámbito, la instrucción más completa fue la Real Orden del 20 de julio de 1789, firmada por el ministro Pedro de Lerena, que instruía a los gobernantes coloniales a enviar porciones de maderas acompañadas de anotaciones indicando sus nombres, usos y dimensiones, además de diseños de las hojas de las árboles de donde habían venido. El Virrey Loreto repasó la orden a sus subordinados, esta vez con resultados muy positivos. En 1791, llegaron a Buenos Aires muestras venidas de Cochabamba, enviadas por el Conde de Casa-Valencia, con una "noticia" relatando "las virtudes conocidas y uso que de ella se hace em aquelles territorios"147. Allá de Cochabamba, por lo menos los gobiernos de Tucumán ${ }^{148}$, Moxos $^{149}$, Córdoba, Salta y Paraguay ${ }^{150}$ respondieron a la solicitud. Los álbumes que acompañaban las remesas, con los diseños de árboles y hojas, están hoy dispersos por diversos archivos españoles.
141. RGHN, doc. 503.

142. AGI, Indiferente General, legajo 1546, doc. 397.

143. Cf. Félix de Azara (1847, v.1, p.78).

144. RGHN, doc. 84 .

145. AGN, Sala 9, legajo 2256, 25-5-12.

146. Cf. Paula De Vos (2007, p.222).

147. AGN, Sala 9, legajo 2257, 25-5-13.

148. Cf. Edberto Óscar Acevedo (1965, p.226).

149. Cf. Valentín Abécia Valdeviso (1989).

150. Sobre las tres últimas gobernanzas, ver AGI, Indiferente General, legajo 1546 , doc. 302 . 
151. Ver Manuel Lucena y Juan Pimentel (1991, p.61).

152. Cf. Bruno Latour (2000, p.364).
Por último, volvemos al caso de las vicuñas y guanacos. La remesa de estos animales desde los Virreinos del Plata y del Perú supera bastante los casos específicos y no sistemáticos que hemos observado. Este ejemplo muestra, perfectamente, que no estaba habiendo una especie de 'desvio' utilitario, que distorsionaba las concepciones de ciencia en España, mientras que, en Francia y en Inglaterra, se desarrollaban las ciencias puras, es decir, las verdaderas ciencias. Al contrario, las ideas de aclimatación y aprovechamiento económico de estos animales estaban en sintonía con lo que había de más actual en el pensamiento científico y económico europeo del período.

La Expedición Malaspina

El cuadro general de las remesas de productos de Historia Natural del Virreinato del Plata para España sufriría una gran mudanza con la llegada a la región de la expedición dirigida por Alejandro Malaspina (1789-1794). Participaron de ella los naturalistas Antonio Piñeda, Luis Neé y Tadeo Haenke, además de seis diseñadores. Esta expedición tuvo el propósito manifiesto de equiparar España a los hechos del capitán Cook y de La Perousse. Era simultáneamente una expedición estratégica, que tenía el objetivo de acompañar los movimientos de los franceses, ingleses y rusos; de verificación del estado políitico-administrativo de las colonias; y de Historia Natural, con el fin de recoger material para el Real Gabinete y para el Real Jardín Botánico ${ }^{151}$. Con la llegada de la expedición, la recolección y remesa de productos de la naturaleza cambiaría completamente de escala y de foco. Entraba en funcionamiento un proceso de recolección de especímenes, que inmediatamente asumían el carácter de artefactos de ciencia "móviles, estables y combinables", tal como teorizó Bruno Latour ${ }^{152}$. Las remesas, antes puntuales, ahora son hechas a los miles. Del objeto singular, típico de la cadena de dádivas, se pasó a la idea de abarcar la totalidad.

Luis Née era el recolector oficial de la expedición. Comenzó a herborizar así que las corbetas La Descubierta y La Atrevida llegaron a Montevideo. Luego, fue para Buenos Aires. Posteriormente, acompañó la expedición naval por la costa de Patagonia y por las Malvinas, para después adentrar el Pacífico. Es posible acompañar las actividades que desarrolló en la región del Virreinato de la Plata a través de sus propias palabras:

1. Habiendo desembarcado en Montevideo, recorri las inmediaciones de aquel puerto, haciendo um acopio bastante considerable de las plantas de sus campos; pasé en compañía del Señor Don Alexandro Malaspina, y del Coronel el Señor Don Antonio Pineda primer encarregado de Historia Natural de la referida expedición, a Maldonado, Pan de azucar, que con singular esmero reconocí hasta u cumbre.

2. Pasé en compañía del referido, a Buenos-Ayres, en donde colecté un buen nuero de plantas no comunes, pasé despues a Maetin Chico, Colonia del Sacramento, San José, el Rosario, Santa Lucia, Canelon, finalmente a Montevideo. 
3. Recorri los campos y orillas del mar cinco leguas distantes del anclage en el Puerto Deseado. Solo.

4. Igalmente todas las inmediaciones del Puerto Egmon. Solo ${ }^{153}$.

En una remesa hecha de Callao, en 1790, envió más un herbario seco de 465 plantas, que incluía, además de los especímenes colectados en Chile y Perú, otros de Montevideo; de la costa patagónica y de las Malvinas ${ }^{154}$. En la región administrativa del Virreinato del Plata, él recogió un total de 775 especímenes ${ }^{155}$.

En una remesa hecha de Callao, en 1790, envió más un herbario seco de 465 plantas, que incluía, además de los especímenes colectados en Chile y Perú, otros de Montevideo; de la costa patagónica y de las Malvinas. En la región administrativa del Virreinato del Plata, él recogió un total de 775 especímenes.

Mientras Née se dedicaba al reino vegetal, organizando herbarios para el Real Jardín Botánico, Piñeda recogía y preparaba animales para el Real Gabinete. José Guio, uno de los diseñadores de la expedición, dio algunos detalles de las recolecciones de ejemplares de fauna. En Montevideo, "se yzo una coleccion de aves disecadas de las mas particulares y raras, como es el Vaja o pájaro Gladiator, la Garza espatula, toda su pluma de color de rosa, gabiotas, perdices, y a repectibes, otras mui preciosas abes, algunos peces raros". En Puerto Deseado "se disecaron una porcion de abes, como son Anades, Ansares, Pajaros Niños o pinguinos, y uma liebre que peso 21 libras y a respectibe otras abes". Por último, cuando la expedición pasó por las Malvinas, "se disecaron cierto numero de abes las mas raras y algunos quadrupedos, y peces" 156.

A continuación, la expedición exploró la costa del Pacífico de América del Sur y del Norte, desde Chile hasta Port Mulgrave, en la actual Alaska. Posteriormente, Malaspina hizo una vasta digresión por el Pacífico, antes de volver por el estrecho de Magallanes y retornar a España. El naturalista Piñeda murió en las Filipinas y fue enterrado allí.

Cuando la expedición volvió a Chile, Née desembarcó y volvió por tierra para el rio de la Plata. Atravesó la cordillera hasta Mendoza y de allí a Buenos Aires, colectando más plantas por el camino. Siguió, entonces, para Montevideo, donde embarcó de vuelta a Europa. En el total de sus viajes, recogió más de 13.000 ejemplares botánicos.

El naturalista bohemio Tadeo Haenke fue un capítulo aparte ${ }^{157}$. Su contratación se dio por indicación de la Universidad de Viena, pero cuando llegó a España, las corbetas de Malaspina ya habían partido. Siguió en un navío comercial a América, que acabó naufragando en la entrada del rio de la Plata. Haenke sobrevivió e inició sus actividades de naturalista herborizando en la región de Montevideo. Cuando llegó a Buenos Aires, más una vez las corbetas habían zarpado, desajuste que estaba previsto en sus instrucciones ${ }^{158}$. El naturalista permaneció en la región por aproximadamente dos meses, herborizando y haciendo
153. MN, ms.2296, f.269 (cf. Carmen Sotos Serrano, 1982, v.1, p.246).

154. MN, ms.1417, f.18 (cf. Carmen Sotos Serrano, 1982, v.1, p.199).

155. MN, ms.1407, f.81 (cf. Carmen Sotos Serrano, 1982, v.1, p.250).

156. MN, ms.1827, f.70 (cf. Carmen Sotos Serrano, 1982, v.1, p.248).

157. Sobre Tadeo Haenke, ver P. Groussac (1900).

158. AGN, Sala 9, legajo 2252, 25-5-8. 
159. Transcripto en Rafael Segredo Baeza y José Ignácio Gonzáles Leiva (2004, p.441). Ver, también MN, ms. 1407, f.18 (Cf. Carmen Sotos Serrano, v.1, p.199).

160. Cf. Thaddaeus Haenke (1830).

161. Cf. Bruno Latour (2000, p.349-355). notas zoológicas y mineralógicas, hasta partir por tierra hacia el Pacífico. En su relato de viaje, Malaspina señaló que

\begin{abstract}
el señor Haenke habia empleado toda su actividade en recorrer las inmediaciones del Río de la Plata, particularmente interesándose hacia las Conchas y el Paraná; parajes a donde no había penetrado por falta de tiempo el señor Née. Luego en las pampas, en la sierra de Mendoza y últimaminte en las cimas de las cordilleras, había recogido un número de plantas, o nuevas o mal caracterizadas, que llegarían próximamente a 1.400, además de diferentes investigaciones en los otros ramos de historia naturall ${ }^{159}$.
\end{abstract}

Por último, fue por tierra a Chile, donde finalmente se reunió con Malaspina y su equipo. Mientras los navíos permanecían en la costa del Pacífico de América del Sur, el naturalista continuó haciendo recolecciones. Adentró por los Andes hasta llegar al río Maranhón, ya en la cuenca amazónica. Pertenece a él la descubierta botánica y la clasificación de la Victoria Regia. Acompañó la expedición por el Pacifico Norte y por la Oceanía y cuando ella retornó a América del Sur, desembarcó en Callao con el permiso de atravesar por tierra hasta Montevideo. Estuvo en Cuzco, Arequipa, La Paz, en el lago Titicaca y en Potosí. Finalmente, sin que se sepa el motivo, se estableció en Cochabamba. Malaspina, que le aguardaba en Montevideo, se cansó de esperar por él y lo dejó atrás. Comenzaba así la segunda parte de las exploraciones de Haenke en América del Sur, ahora en la condición irregular de naturalista residente. Durante años, Tadeo Haenke vivió en Cochabamba, donde compró una hacienda, en la cual se dedicó a escribir y organizar el material de sus viajes anteriores. Continuó también con sus actividades de naturalista.

En la doble condición de naturalista originario del Imperio Austríaco, pero a servicio de la corona española, Haenke hizo colecciones en duplicada, que acabaron llegando a las instituciones científicas de España y Bohemia. Los herbarios mandados para Praga dieron base a la publicación de una flora, la Reliquiae Haenkeanae, donde están descritas diversas especies de la región administrativa del Río de la Plata ${ }^{160}$. Los nombres botánicos atribuidos por el naturalista a algunas plantas, como la Malaspinea laurifolia, muestran cuanto era viva la cultura de la dádiva y cuanto ella persistía en un universo que tendemos a ver como científico e impersonal.

\section{Conclusión o No todo lo que viene a la red es pescado}

La noción de red desarrollada por Bruno Latour, no obstante ser útil para el entendimiento del proceso, implica en algunas dificultades. Aunque no se compadezca por lo que describe, Latour hace una lectura triunfalista del mundo de las ciencias. En este sentido, su texto clásico sobre el encuentro entre Lapérouse y los nativos de las Sacalinas es ejemplar ${ }^{161}$. En primer lugar, es necesario tener en cuenta que Latour remite al siglo XVIII, aunque por analogía, procesos científicos de laboratorio que en la época aún no se habían imaginado. El otro gran problema es que el sociólogo, así como la gran mayoría de los autores europeos y 
norteamericanos, se muestra profundamente impregnado por el mito científico de la "descubierta". No es casual que Latour compare D. Juan I de Portugal y sus navegadores con Luís XVI y Lapérouse.

Por más interesante que sea, la perspectiva analítica de la "descubierta del otro" dice muy poco al siglo XVIII. En los casos de España y Portugal, eran ya 200 años de dominación, convivencia y mestizaje, y en los de Francia, Holanda e Inglaterra, algo menos que eso. El propio Lapérouse, aunque francés de nacimiento, era un hombre de las colonias, casado con una creóle. También creóle, nacida en Martinica, fue la Emperatriz Josefina que, como hemos visto, estaba profundamente envuelta con los procesos de aclimatación de animales y plantas americanas en Europa. Cook, en el Pacífico, fue la excepción y no la regla. En grados diversos, que en orden creciente va de Inglaterra, Francia, España a Portugal, los cientistas viajeros setecentistas eran nacidos en las colonias, o en ellas radicados hace mucho tiempo. La extrañeza exagerada es antes un efecto literario, producido deliberadamente por los relatos de viajes, que un 'hecho científico'. Había en esto una doble estrategia. Desde el punto de vista de la literatura, los autores buscaban despertar en el lector el interés por lo exótico y por la novedad, algo muy característico de este género literario desde su surgimiento en la antigüedad ${ }^{162}$. Desde el punto de vista de las estrategias imperiales, al negar el secular contacto e insistir en la idea de los descubrimientos, Inglaterra y Francia estaban afirmando que ellos se habían convertido en los portugueses y españoles de otros tiempos y, por lo tanto, a ellos pertenecían los nuevos territorios 'recién descubiertos'.

En el siglo XVIII, la polaridad entre europeo y nativo hace mucho tiempo había desaparecido. Sin embargo, la oposición primaria entre culturas, razas, géneros, etc. tiene público cierto entre los devotos de ciertos revisionismos, que prefieren tratar con un mundo simplificado hecho de polaridades simples: exploradores $x$ explorados, europeos $x$ nativos, etc. $x$ etc. Para que entendamos el mundo del siglo XVIII, hecho de poblaciones viviendo secularmente 'en contacto', es preciso deconstruir, tornando complejos, los esquemas de carácter bipolar y simplistas - nosotros y los otros - que han servido de base metodológica y epistemológica para historiadores, antropólogos, lingüistas, etc., incluso para los que se proponen hacer abordajes vinculadas a los estudios culturales y postcoloniales ${ }^{163}$.

Las expediciones de conquista y exploración de la región del Río Negro se prestan ejemplarmente a abordajes sociológicas del tipo actor-red, una vez que ellas fueron responsables por producir "inscripciones" científicas "móviles, estables y combinables", tal como lo propuesto por Latour ${ }^{164}$, que iban de los relatos y mediciones a las capturas de ñandúes y guanacos enviados a Madrid. Pero el mundo casi aséptico descrito por el sociólogo, que llega a comparar los navíos de Lapérouse a las astronaves norteamericanas, está lejos de describir mínimamente el proceso mediante el cual el conocimiento local de los salvajes se transformaba en conocimiento universal ${ }^{165}$.
162. Cf. Juan Pimentel (2003, p.41-42).

163. Ver, Magnus R. de M. Pereira y Ana Lúcia R. B. Cruz da (2006, p.382).

164. Cf. Bruno Latour (2000, p.364).

165. Idem, p. 351 . 
166. AGN, Sala 9, legajo 2257, 25-5-13.

167. Cf. Bruno Latour (2000, p.352).

168. Cf. David J. Weber (2007, p.365 e ss).
Tornemos al caso de los camélidos, que se presta al mismo tiempo para concordar con Latour y sus seguidores, y para discordar de ellos, por la necesidad hacer más complejos sus esquemas un tanto simplistas. Martin de Garay, miembro de la Junta Suprema Central, que gobernó España durante la ocupación napoleónica, ordenó que el Virrey de Buenos Aires tomase una serie de medidas complementarias al envío de vicuñas, llamas y guanacos a Europa.

\footnotetext{
V. E. disponga que por personas practicas e inteligentes en todo lo concerniente a la historia natural de los expresados animales, se extienda una noticia circunstanciada del clima, alimentos, y cuidado que necesitan $\mathrm{p}^{a}$ su subsistencia y propagacion, de las enfermedades a que están expuestos y de su curacion, de las preparaciones que se necesita $p^{a}$ quitarles la lana y aprovecharse de ella, y por ultimo de gto sea preciso saber $p^{a}$ fomentar en esta Peninsula la cria de unos animales tan preciosos ${ }^{166}$.
}

Además, junto con los animales y sus 'manuales de instrucción', deberían ser enviadas "una ó dos personas das que están acostumbradas a cuidarlos". Como se observa, y en este sentido las concepciones de Latour son perfectas, no bastaba que los animales fuesen incluidos en la red. Era necesario se apropiar del conjunto de los conocimientos nativos, lo que él llamaría de etno-zoología, a fin de elaborar en las instituciones de Madrid y Cádiz un conocimiento zoológico científico europeo: la Zoología. Sin embargo, el proceso en que esto se produjo contrasta mucho con el imaginario de laboratorio pasteurizado. El mundo por donde se movía tanto Lapérouse cuanto sus correspondientes ingleses, portugueses y españoles estaba muy lejos de este mundo supuestamente controlado por la ciencia.

Aún teniendo en vista nuestro ejemplo, apropiarse de los conocimientos nativos en muchos casos implicaba apropiarse de los propios nativos, como en el caso de las "chinas" que cuidaban de los ñandúes y de los guanacos. Y no es esta solamente la cuestión, pues la captura de chinas y animales por las expediciones militares-exploratorias del Río Negro se dio en un contexto muy diverso de aquel del encuentro primero entre Lapérouse y los nativos de las Sacalinas. "Lapérouse cruza el camino de los pescadores chinos en ángulo recto; nunca se han visto antes y los grandes navíos no están ahí para quedarse"167. Ya las expediciones a los territorios "bárbaros" remanentes de América del Sur envolvían, además de hombres de ciencia, personas originarias de tribus indígenas secularmente conocidas e integradas, populaciones menos alcanzadas por el contacto y que se mantenían autónomas en delicado equilibrio de frontera ${ }^{168}$. criollos hispano-platinos socialmente blancos, mestizos de todo tipo, que formaban la base social de esta sociedad, gobernantes y tropas coloniales de origen europea. Es decir, el encuentro no se daba en ángulo recto y los exploradores estaban ahí para quedarse.

Desde la década de 1770, estaban siendo organizadas diversas expediciones de conquista de la Patagonia, que iban de las simples campañas punitivas contra indígenas insumisos a otras de reconocimiento del terreno. Esto hacía parte del cuadro estratégico y defensivo provocado por la carrera científica e imperial del período. Eran la contrapartida de los viajes de Cook o de Bougainville, 
que entre otros resultados habían provocado la quiebra del status quo entre indios y españoles. España se vio impelida a avanzar sobre la Patagonia y California antes que Inglaterra, Francia o Rusia lo hiciesen. Para asegurar la pose, en algunos casos esas expediciones promovieron el exterminio sistemático de los indígenas de sexo masculino de las tribus consideradas rebeldes. Es el caso de la campaña contra los Pehuenches llevada a cabo por José Francisco de Amigorena, Gobernador de Mendoza y Comandante General de las Fronteras, en 1780. La narrativa del suceso español fue hecha con no poco cinismo.

Se han tomado 123 prisioneros entre mugeres, niña y niños de 10 á 11 años para bajo. [...] A las prisioneras se les trata com humanidad con que se me esplicó la prevencion de V. E., no permitiendo se les llegase á su ropa; conduciendolas á esta [Mendoza], donde quedan distribuidas en casas de mi satisfacion, para su cuidado y educación. No se há traido indio grande algunos, porque los que no pudieram escaparse en la accion lque fueram pocos) quisieram mas bien morir que entregarse ${ }^{169}$.

Expediciones como esta, que envolvían los comandantes de frontera, podrían tener simultáneamente el carácter 'científico' de reconocimiento del terreno, además de ciertas encomiendas de animales venidas de España que eran repasadas a sus jefes. El botín de estas batallas científico-territoriales eran las indias, ñandúes y guanacos, que podrían acabar en la Casa de Reclusión Femenina de Buenos Aires, donde los animales eran tratados por las prisioneras hasta su inclusión en la red de remesas científicas. No vea el lector en esto otro ejemplo que confirma la tesis de la barbarie específicamente española. En los espacios coloniales portugueses, holandeses, franceses e ingleses los procedimientos eran exactamente los mismos.

Si queremos pintar un cuadro aún más complejo, basta recordar que en muchos casos los animales reducidos a muestras "móviles, estables y combinables", obtenidos a través de los métodos que hemos acabado de describir, estaban lejos de fluir como "inscripciones" en la gran tela científica. Muy por el contrario, fluían antes como regalos en cadenas de dádivas típicas del Antiguo Régimen. No se debe olvidar que los actos de producir tales artefactos de ciencia podrían ser exactamente los mismos que producían otra modalidad de dádiva, aquella de distribuir criadas domésticas semi-esclavas para las familias bonaerenses y mendocinas, 'regalos' a través de los cuales los gobernadores cimentaban sus alianzas con las élites locales. En cuanto a los animales, al llegar a las leoneras del Retiro o de Aranjuez, se tornaban signos ostentosos de grandeza imperial o de la modernidad de la casa reinante y no las "inscripciones" abstractas propuestas por Latour. Sólo después de la muerte, los cadáveres de estos especímenes eran recogidos para finalmente descansar en paz en la red científica.

Diversos autores han procurado enfrentar teóricamente la naturaleza de los contactos y de la transferencia de conocimientos que se daban en las regiones de expansión europea. La noción de "zona de contacto", refinada por Mary Louise Pratt, procura tratar de cubrir este tipo de situación ${ }^{170}$. Sin embargo, aunque llena de intenciones revisionistas, la autora se mantiene estrictamente en el imaginario de
169. Cf. José Francisco de Amigorena (1836, v.4, p.109-110).

170. Cf. Mary Louise Pratt (1999, p.32). 
171. Idem, p.251-2.

172. Cf. Magnus R. de M. Pereira y Ana Lúcia R. B. Cruz da (2006, p.383).

173. Cf. Londa Schiebinger (2005, p.125 e ss).

174. Cf. Paula De Vos (2007, p.209).

175. Distorsión que acostumbra ser más acentuada aún por el cómputo, como remesas científicas vegetales, del envío de calaguala, canchalagua, bálsamo aguraybay, aceite Maria, aceite de copaiba y ciertas hierbas medicinales que eran remitidas ya en la condición de productos comerciales de uso medicinal consagrado, para abastecer a las Reales Boticas, y no tanto como productos para experimentación farmacéutica. la oposición primaria de los encuentros iniciales entre civilizaciones y, más que eso, en el cuadro del pensamiento imperial británico. Pratt no tiene ninguna dificultad en afirmar que W. B. Stenvenson "exageró sólo un poco" al decir, en 1825, que, "sin la menor exageración", no obstante las tierras de América del Sur "hayan sido descubiertas en el siglo XVI, permanecieron casi desconocidas hasta principios del $X \mid X^{\prime \prime}{ }^{171}$. ¿Desconocidas en qué condiciones? O ¿para quién? es preciso preguntar a la autora ${ }^{172}$. Los problemas del concepto de zona de contacto, tal como lo emplea Pratt, no escaparon a la reflexión de Londa Schiebinger, para quien su uso ha llevado a una noción excesivamente rígida de los no-europeos como "otros". Por motivos diferentes de los nuestros, la historiadora alemana también intenta mostrar la complejidad de las interacciones en este espacio que ella llama de "biocontacts Zones"173.

También merecen ser observadas con cautela los abordajes excesivamente economicistas de la cuestión de las redes de remesas de productos naturales. Paula de Vos, buscando mostrar el carácter utilitario y económico de las remesas de las colonias españolas, contabilizó que aproximadamente el $87 \%$ de ellas eran constituidas de especímenes botánicos para uso medicinal y económico ${ }^{174}$. Recordamos que, al hacer este tipo de lectura la autora tiene por objetivo afirmar que eso era un patrón general europeo y no una exclusividad española. Sin embargo, es posible decir que el abordaje estadístico más oscurece que contribuye para aclarar el cuadro general de esas remesas.

Si hiciésemos una contabilidad de los especímenes colectados en el área administrativa del Virreinato del Río de la Plata y enviados a las instituciones científicas españolas, llegaríamos a un número aún más expresivo: más del $95 \%$ pertenecían al reino vegetal. Este porcentaje es engañoso, sin embargo, pues está completamente distorsionado por las recolecciones masivas de especímenes botánicos hechas por Née y Haenke ${ }^{175}$. Si la distorsión provocada por las recolecciones de la Expedición Malaspina no fuese considerada y mirásemos para el total de las remesas a partir de un punto de vista cualitativo, llegaríamos a una conclusión muy distinta de la de De Vos. Diríamos que en la Plata preponderaron ampliamente las recolecciones de cuño específicamente científico, pues era ese el objetivo inmediato de los naturalistas involucrados, también admitiendo que en el propósito científico estaban embutidas grandes dosis del orgullo imperial y vanas esperanzas económicas. Recolecciones hechas así poco se prestaban a propósitos utilitarios. Ni siquiera eran eficaces desde el punto de vista de la clasificación botánica, pues el método linneano hacía necesario el acompañamiento del ciclo vegetativo de las plantas. De este modo se entiende porque la recolección de miles de especímenes resultaron en floras de las cuales sólo constan unos pocos cientos de variedades botánicas.

Volviendo a la estadística que totaliza más del 95\% de remesas botánicas, es posible decir que, a pesar de este amplio porcentaje, no era este el formato preponderante de la red científica en el río de la Plata. Antes, podríamos decir que fueron las remesas animales que proporcionaron el tono. Esto porque, como hemos 
visto, las cadenas de dádivas continuaban activas. Cuando no eran las dádivas animales eran ciertos productos zoológicos y botánicos de cuño utilitario, como el mate, caraguatá o plumas de ñandúes, enviados para atender a los pedidos específicos de una u otra gran figura de la corte. El cuadro general de las remesas del Virreinato del Río de la Plata no permite que lleguemos a conclusiones similares a las de De Vos: "As Shiebinger, Cook and Steven Harris have pointed out in various essays, colonial natural history was 'big science' and 'big business' - and in our case, part of 'big government' as well, at least in absolutist Spain" 176. De hecho, como ya hemos señalado, y gran parte de la actual historiografía sobre el tema lo ha hecho, ciencia y utilitarismo convergen en este momento en toda Europa. Sin embargo, esto no significa aceptar que el absolutismo estaría moldeando la ciencia producida en España, dándole un exclusivo carácter oficial. La autora parece olvidar que toda la "big science" del período tenía esto mismo carácter oficial, independientemente de la cuestión del absolutismo. Las coronas fueron las principales responsables por patrocinar los complejos científicos. Las redes administrativas y las científicas se confundían tanto en España, como en Francia, en Portugal y en Inglaterra. ¿Cuál es la diferencia de una expedición como la de Cook, promovida y controlada por el Almirantazgo de Inglaterra; las francesas, por la Académie Royale des Sciences, y la de Malaspina, por el Ministerio de la Marina de España? ¿qué tornaba una más o menos "big administration" que la otra?

Apelar al largo brazo administrativo de la corona no parece tipificar la ciencia española. Detrás de esta noción de "gran administración" parece estar lo que hemos llamado de cultura de la dádiva. Sin embargo, esto tampoco proporciona características especificas a las redes españolas, una vez que por toda Europa ocurrieron los mismos procesos de superposición de las redes científicas y administrativas, sujetas aún a la cultura política del Antiguo Régimen, fuesen las coronas absolutistas o no.

No se pretende afirmar, sin embargo, que el impacto del absolutismo es nulo en el proceso de constitución y funcionamiento de las redes científicas, pero que este impacto se daba en momentos posteriores. Para una mejor comprensión, volvemos a la expedición de Lapérouse, el clásico ejemplo de Bruno Latour, pero comparándola con las expediciones de Alessandro Malaspina. Aunque las fragatas Boussole y Astrolabe hubiesen misteriosamente desaparecido en el Pacífico, con Lapérouse y toda la tripulación, esta expedición no fue un fracaso, como bien advierte el sociólogo. Por dos veces el comandante envió anotaciones científicas para Francia, haciéndolas sobrevivir al desastre y que sus datos fuesen incorporados por la ciencia europea. A pesar de la carrera científica y colonial, esto sólo fue posible con la colaboración rusa e inglesa.

La historia de la expedición Malaspina fue muy diferente. Las fragatas La Descubierta y La Atrevida, después de un largo recorrido por América y el Pacífico, retornaron a España abarrotadas de los más variados registros y productos científicos. Sin embargo la expedición comandada por Malaspina se puede considerar un fracaso. Por exceso de cuidados estratégicos, los relatos de viaje no fueron
176. Cf. Paula De Vos (2007, p.212). 
publicados. Acusado de conspirador por Manuel Godoy, Malaspina acabó detenido. Excluida la flora de Haenke, publicada póstumamente en Praga, las recolecciones botánicas y zoológicas no resultaron en importantes contribuciones científicas inmediatas y principalmente no dieron visibilidad a la ciencia producida en España, que era uno de los principales propósitos de la expedición. En resumen: el esfuerzo científico fue en gran medida desperdiciado. El proceso tiene muchos puntos comunes con lo que ocurrió con nuestro conocido viaje filosófico de Alexandre Rodrigues Ferreira, cuyos resultados también fueron desperdiciados por la corona portuguesa.

Lo que se puede inferir de estos casos es que las coronas absolutistas ibéricas trataban la ciencia de forma inconstante, lo que truncaba el proceso acumulativo que puede ser observado en Inglaterra o en Francia. Interesa, por lo tanto, saber el porqué de las instituciones científicas de los países ibéricos se mostraren tan dependientes de las voluntades inmediatas de las coronas. El problema no estaba tanto en el absolutismo, ya que los diversos absolutismos europeos no produjeron un tipo de ciencia intrínsecamente diferente. Por el contrario, contribuyeron para la misma reserva común del desarrollo de la ciencia en Europa. Lo que se observa es que, en España y en Portugal, la ciencia aún no tenía implantación social suficiente para evitar que las coronas la tratase según otros "caprichos" o designios, que no los científicos. En la Península Ibérica, la ciencia aún no había salido del laboratorio y colonizado la sociedad, al punto de imponer ciertos límites a las propias prácticas de los reyes.

\section{REFERÊNCIAS}

\section{FUENTES IMPRESAS}

ALVARES DE QUINDOS Y BAENA, Juan Antonio. Descripcion histórica del Real Bosque y Casa de Aranjuez. Madrid, Imprenta Real, 1804.

AMIGORENA, José Francisco de. Diario de la expedicion, que de órden del Exmo. Señor Virey acabo de hacer contra los indios bárbaros Peguenches.[1780] In: DE ANGELIS, Pedro. Coleccion de obras y documentos relativos á la historia antigua y moderna de las provincias del Rio de la Plata. Buenos Aires: Imprenta del Estado, 1836. v.5. p.103-115.

AZARA, Félix de. Apuntamentos para la Historia Natural de los Páxaros. Madrid: Hija de Ibarra, 1802a. 3v.

Apuntamentos para la Historia Natural de los quadrúpedos del Paragüay y Rio de La Plata. Madrid: Viuda Ibarra, 1802b. 2.v.

Descripción e historia del Paraguay y del Río de la Plata. Madrid: Imprenta de Sanchiz, 1847. 2.v. 
BOURGOING, J. F. Tableau de l'Espagne Moderne. Paris: chez l'Auteur, 1797. 3.v.

BRU, Juan Bautista. Colección de láminas que representan los animales y monstruos del Real Gabinete de Historia Natural de Madrid con una descripción individual de cada uno. Madrid: Imprenta de Andrés de Sotos, 1786. 2.v.

[BUFFON] LECLERC, Georges Louis. Histoire Naturelle. Paris: Imprimérie Royale, 1765.

CUVIER, Georges. Notice sur le squelette d'une três grand espèce de Quadrúpede inconnue, truvé au Paraguay, et déposé au Cabinet d'Histoire Naturelle de Madrid. Magasin Encyclopédique, v.2, n.1, 1796. p.303-3010.

CUVIER, Georges. Sur le Meghaterium. Annales du Muséum d'Histoire Naturalle, n.5, 1804. p.358-387.

DILLON, John Talbot. Travels through Spain with a View to Illustrate the Natural History. Dublin: S. Price, 1781.

FALKNER, Thomas. Descripción de la Patagonia y de las partes contiguas de la América del Sur. Buenos Aires: Hachette, 1957.

FRANCO DÁVILA, Pedro. Instrucción becha de órden del Rei N. S. para que los Virreyes, Gobernadores, Corregidores, Alcaldes Mayores é Intendentes de Provincias en todos los Dominios de S. M. puedan hacer escoger, preparar y enviar á Madrid todas las producciones curiosas de Naturaleza que se encontraren en las Tierras y Pueblos de sus distritos, á fin de que se coloquen en el Real Gabinete de Historia Natural que S. M. ha establecido en esta corte para beneficio é instrucción pública. Mercurio Historico y Politico, t.2, mayo1776. p.94-134.

GARRIGA, José. Descripción de un esqueleto de un quadrúpedo muy corpulento y raro, que se conserva en el Real Gabinete de Historia Natural de Madrid. Madrid: Viuda Ibarra, 1796.

GODOY, Manuel de. Cuenta dada de su vida política por Don Manuel Godoy, Príncipe de la paz: Ó sean memorias críticas y apolgeticas para la historia del reinado del señor D. Carlos IV de Borbon. Madrid: Impr. de I. Sancha, 1836. 3.v.

GÓMEZ ORTEGA, Casimiro. Instrucción sobre el modo más seguro y económico de transportar plantas vivas por mar y tierra á los paises mas distantes. Madrid: Joaquín Ibarra, 1779.

HAENKE, Thaddaeus. Reliquiae Haenkeanae: seu descriptiones et icones plantarum quas in America meridionali et boreali, in insulis Phillipinis et Marianis collegit Thaddaeus Haenke. Pragae: J. G. Calve, Bibliopam, 1830.

HULTMAN, David. Instructio musei rerum naturalium. Upsaleæ: Magnus Hojer, 1753.

LA CONDAMINE, Charles-Marie. Viagem na América Meridional descendo o Rio das Amazonas. Brasília : Senado Federal, 2000.

Magasin Encyclopédique, tomo 3, mai-juin1805.

MONTESQUIEU. Oeuvres complètes. Paris: Gallimard, 1941.

NORDBLAD, Ericus. Instructio peregrinatoris. Upsala: 1759. In: LINN/EI, Caroli. Amcenitates academica. v.5. Holmiæ: Laurentii Salvii, 1760. 
ORTIZ DE AYALA, Tadeo. Resumen de la estadística del Imperio Mexicano. Ciudad de México: Imprenta de Doña Herculana de Villar, 1822.

Real cédula de S. M., en que se mandan observar el reglamento provisional para el gobierno económico, y método de enseñanza de la botánica en el Real Jardín de Cartagena. Madrid: Viuda de Ibarra, 1787.

ROMÉ DE L'ISLE, Jean-Baptiste Louis de. Catalogue systématique et raisonné des curiosités de la nature et de l'art, qui composent le cabinet de M. Davila, avec figures en taille douce, de plusieurs morceaux qui n'avoient point encore été gravés. Paris: Briasson, 1767.

\section{FUENTES MANUSCRITAS}

AGI - Archivo General de Indias, Sevilla (La numeración de los documentos relativos a los especímenes de plantas se indica según el catálogo organizado por Maria Teresa Lopez Dias e Antonio Dominguez Camacho (1983).

AGN - Archivo General de la Nación, Buenos Aires

AGP - Archivo General de Palácios, Madrid

MN - Museo Naval, Madrid (Citado y numerado de acuerdo con Carmen Soto Serranos (1982).

MNHN - Museo Nacional de Historia Natural, Madrid (La numeración de los documentos relativos a las expediciones españolas fueron referenciados de acuerdo con el catálogo organizado por María de los Ángeles Calatyd (1984).

RGHN - Real Gabinete de Historia Natural, Madrid (La numeración de los documentos de Real Gabinete de Historia Natural, que comprende la colección del Museo Nacional de Historia Natural, se indica según los catálogos organizados por María de los Ángeles Calatyd (1987; 2000).

RJB - Real Jardin Botánico, Madrid

LIBROS, PERIODICOS, TESIS

ABÉCIA VALDEVISO, Valentín. Lazaro de Rivera y la riqueza botanica de Moxos en el periodo de Carlos III. Historia y Cultura, La Paz, n.15, p. 27-33, 1989.

ACEVEDO, Edberto Óscar. La Intendencia de Salta del Tucumán en el Virreinato del Río de la Plata. Tucumán: Universidad Nacional de Cuyo, 1965.

ANDERSON, Warwick. Climates of Opinion: Acclimatization in Nineteenth-Century France and England. Victorian Studies, v.35, n.2, p.137-157, 1992.

BARATAS DÍAZ, Luis Alfredo. El núcleo de instituciones científicas matritenses en el Paseo del Prado desde el siglo XVIII. Asclepio, Madrid, v.48, n.1, p.183-217, 1996. 
BARRAS DE ARAGÓN, Francisco de las. Una carta de D. Félix de Azara y algunas noticias de sus trabajos, según documentos del Archivo de Indias de Sevilla. Boletín de la Real Sociedad Española de Historia Natural, Madrid, t.15, p.361-366, 1915.

BRAVO, Michael T. Ethnographic Navigation and Geographical Gift. In: LIVINGSTONE, David N., WITHERS, Charles W. (org.).Geography and Enlightenment. Chicago: University of Chicago Press, 1999. p.199-335.

BRIGGS, Robin. The Académie Royale des Sciences and the Pursuit of Utility. Past and Present, Oxford, n.131, p.38-88, 1991.

CABRAl CHAMORRO, Antonio. O jardim botánico Príncipe da Paz de Sanlúcar de Barrameda: uma instituição ilustrada ao serviço da produção agrária e florestal. Revista de Estudos Andaluces, Sevilla, n.21, p.165-188, 1995.

CABRERA, Angel. El concepto de tipo en zoología y los tipos de mamíferos del Museo de Ciencias Naturales. Trabajos del Museo de Ciencias Naturales, Madrid, n.1, p.3-32, 1912.

CALATAYUD, María de los Ángeles. Catálogo crítico de los documentos del Real Gabinete de Historia Natural. (1787-1815). Monografías. Madrid: Museo Nacional de Ciencias Naturales/ CSIC, 2000.

Catálogo de documentos del Real Gabinete de Historia Natural. (1752-1786) Madrid: Museo Nacional de Ciencias Naturales/CSIC, 1987.

Catálogo de las expediciones y viajes científicos españoles. Siglos XVIII y XIX. Madrid: Museo Nacional de Ciencias Naturales/CSIC, 1984.

CAÑIZARES-ESGUERRA, Jorge. Nature, Empire and Nation, Exploration of the History of Science in the Iberian World. Stanford: Stanford University Press, 2006.

CLÉMENT, Jean-Pierre. Las instituciones científicas y la difusión de la ciencia durante la Ilustración. Madrid: Akal, 1993.

COOK, Harold J. Matters of Exchange: Commerce, Medicine, and Science in the Duch Golden Age. New Haven: Yale University Press, 2007.

COWIE, Helen. Sloth Bones and Anteater Tongues: Collecting American Nature in the Hispanic World (1750-1808) Atlantic Studies, Abingdon, v.8, p.5-27, 2011.

CRUZ, Ana Lúcia R.B. Verdades por mim vistas e observadas Oxalá foram fábulas sonhadas; cientistas brasileiros do Setecentos, uma leitura auto-etnográfica. Tese (Doutorado em História), Universidade Federal do Paraná, Curitiba, 2004.

DAVIS, Natalie Zemon. The Gift in Sixteenth-Century France. Madison: The University of Wisconsin Press, 2000.

DE VOS, Paula. Natural History and the Pursuit of Empire in Eighteenth-Century Spain. Eighteenth-Century Studies, New York, v.40, n.2, p.209-239, 2007.

The Rare, the Singular, and the Extraordinary; Natural History and Collections of Curiosities in the Spanish Empire. In: BLEICHMAR, Daniela et al. (Org.) Science in the Spanish and Portuguese empires. 1500-1800. Stanford: Stanford University Press, 2009. p.269-289. 
DRAYTON, Richard Harry. Nature's Government: Science, Imperial Britain, and the 'Improvement' of the World. London: Yale University Press, 2000.

FURLONG, Guillermo. Naturalistas argentinos; durante la dominación hispánica. Buenos Aires: Editoria Huarpes, 1948.

GÓMEZ-CENTURIÓN, Carlos. Curiosidades vivas; Los animales de América y Filipinas en la Ménagerie real durante el siglo XVIIII. Anuario de Estudios Americanos, Sevilla, v.66, n.2, p.181-211, 2009.

GONZÁlEZ BUENO, Antonio. El Jardín de la Paz. Cádiz Iberoamérica, Cádiz, n.3, p.30-34, 1985.

GONZÁlES BUENO, Antonio; RODRÍGUEZ NOZAL, Raúl. Plantas americanas para la España ilustrada. Madrid: Editorial Complutense, 2000.

GONZÁLEZ ENCISO, Agustín. Estado e industria en el siglo XVIII: la Fábrica de Guadalajara. Madrid: Fundación Universitaria Española, 1980.

GROUSSAC, P. Noticia de la vida y trabajos científicos de Tadeo Haenk. Anales de la Biblioteca, Buenos Aires, v.1, p.17-57, 1900.

HESPANHA, António M. La economia de la gracia. tro de Estudios Constitucionales, 1993. La gracia del derecho. Madrid: Cen-

HOAGE, R. J.; DEISS, William A. New Worlds, New Animals; From Menagerie to Zoological Park in Nineteenth Century. Baltimore: The Johns Hopkins University Press, 1996.

HUARD, Pierre; WONG, Ming. Les enquêtes scientifiques françaises et l'exploration du monde exotique aux XVIIe et XVIIIe siécles. Bulletin de l'Ecole Française d'Extrême-Orient, Paris, v.52, p.143-155, 1964.

KOERNER, Lisbet. Linnaeus; Nature and Nation. Cambridge: Harvard University Press, 2000.

KURY, Lorelai. Homens de ciência no Brasil: impérios coloniais e circulação de informações (1780-1810). História, Ciências, Saúde: Manguinbos, Rio de Janeiro, v.11 (suplemento 1), p.109-129, 2004.

KURY, Lorelai; CAMENIETZKI, Carlos Z. Ordem e natureza: coleções e cultura científica na Europa Moderna. Anais do Museu Histórico Nacional, Rio de Janeiro, n.29, p. 57-85, 1997.

LACROIX, Sylvie. Sir Joseph Banks et l'envoi de naturalistes dans les explorations anglaises (1765-1820). Dix-huitième siècle, Paris, n.22, p. 121-126, 1990.

LAFUENTE, Antonio; MAZUERCOS, Antonio. La academia itinerante: la expedición franco-española al Reino de Quito de 1736. In: SELLÉS, Manuel et al. (orgs.) Carlos III y la ciencia de la Ilustración. Madrid: Alianza Editorial, 1987. p.299-312.

LATOUR, Bruno. Centrais de cálculo. In: Ciência em ação: como seguir cientistas e engenheiros sociedade afora. São Paulo: Unesp, 2000. p.349-424.

LOPEZ DIAZ, Maria Teresa; DOMINGUEZ CAMACHO, Antonio. Catálogo de documentos histórico farmaceuticos del Archivo General de Indias. Sevilla: Publicaciones de la Universidad de Sevilla, 1983. 
LÓPES PINHERO, José M.; GLICK, Thomas. El megatério de Bru y el presidente Jefferson; una relación insospechada en los albores de la paleontologia. Valencia: Instituto de Estúdios Documentales e Históricos sobre la Ciencia, 1993.

LUCENA, Manuel; PIMENTEL, Juan. Los "Axiomas políticos sobre la América" de Alejandro Malaspina. Madrid: Doce Calles, 1991.

LUCENA GIRALDO, Manuel; PEDRO, Antonio E. de. La Frontera Caribica: Expedicion de Limites al Orinoco. 1754-1761. Caracas: Departamento de Asuntos Públicos de Legoven, 1992.

MAUSS, Marcel. Ensaio sobre a dádiva; Forma e razão da troca nas sociedades arcaicas. In : Sociologia e Antropologia. v.2. São Paulo: Edusp, 1974.

MAZO PÉREZ, Ana Victoria. El oso hormiguero de su majestad. Asclepio, Madrid, v.6, n.1, 2006. p.281-294.

MONTERO, Angel; DIÉGUEZ, Carmen. Datos para la paleontologia chilena; La paleontología en la expedición Heuland a Chile y Perú. (1795-1800). Asclepio, Madrid, v.50, n.1, 1998. p.6978.

MONES, Alvaro; KLAPPENBACH, Miguel A. Um ilustrado aragonés en el Virreinato del Río de la Plata: Félix de Azara (1742-1821). Montevideo: Museo Nacional de Historia Natural, 1997.

OLIVEIRA, Ricardo de. Valimento, privança e favoritismo: aspectos da teoria e cultura política do Antigo Regime. Revista Brasileira de História, São Paulo, v.25, n.50. p.217-238, 2005.

OLMI, Giuseppe. Théatres du monde, les collections européenes des XVIe et XVIIe siècles. In: SCHAER, Roland (org.). Tous les savoirs du monde, Enciclopédies et bibliothèques, de Sumer au XXe. siècle. Paris: Bibliothèque Nationale de France, 1996. p.272-277.

OSBORNE, Michael A. Acclimatizing the World: A History of the Paradigmatic Colonial Science. Osiris, Chicago, 2nd Series, v.15, 2000. p.135-151.

PELAYO, Francisco. El mito de los gigantes americanos; Un debate de la paleontología de vertebrado española durante la época colonial. In: BÉNASSY, Marie-Cécile. Nouveau monde et renouveau de l'histoire naturelle, v.3. Paris: Presses Sorbonne Nouvelle, 1994. p.161-182.

Pebr Lófling y la Expedición al Orinoco. 1754-1761. Madrid: Sociedad Estatal Quinto Centenario. 1990.

PEREIRA, Magnus Roberto de Mello. Um jovem naturalista num ninho de cobras; A trajetória de João da Silva Feijó em Cabo Verde em finais do século XVIII. História: Questões E Debates, Curitiba, n.36, 2002. p.27-60.

PEREIRA, Magnus R. M.; CRUZ, Ana Lúcia R. B. O viajante instruído; os manuais portugueses do iluminismo sobre métodos de recolher, preparar, remeter, e conservar productos naturais. In: DORÉ, Andréa; SANTOS, Antonio C. A. Temas Setecentistas; Governos e populações no Império Português. Curitiba: UFPR/Fundação Araucária, 2009. p.242-251.

. A história de uma ausência: os colonos cientistas da América portuguesa na historiografia brasileira. In: FRAGOSO, João et al. (org.). Nas rotas do Império. Vitória/Lisboa: Edufes/IICT, 2006. p.357-390. 
PIMENTEL, Juan. Testigos del mundo; Ciencia, literatura y viajes em la ilustración. Madrid: Marcial Pons, 2003.

PRATT, Mary Louise. Os olhos do império; relatos de viagem e transculturação. Bauru: Edusc, 1999.

PUIG-SAMPER, Miguel A. Difusión e institucionalizacíon del sistema linneano. In: LAFUENTE, Antonio et ali. (Orgs.) Mundialización de la ciencia y cultura nacinal. Aranjuez: Doce Calles, 1993. p.349-359.

SEGREDO BAEZA, Rafael; GONZÁLES LEIVA, José Ignácio. La expedición Malaspina en la frontera austral del imperio español. Santiago: Editorial Universitaria, 2004.

SCHIEBINGER, Londa. European Naturalists in the West Indies. In: SCHIEBINGER, L.; SWAN, C. . Colonial Botany; Science, Commerce, and Politcs in the Early Modern World. Philadelphia: University of Pensilvania Press, 2005.

SOLER JARDÓN, Fernando. Tres tigres para el Buen Retiro. Revista de Indias, Madrid, v.28-29, 1947. p. 501-508.

SOTOS SERRANO, Carmen. Los pintores de la expedición Alejandro Malaspina. Madrid: Real Academia de Historia, 1982.

SPARY, Emma. Utopia's Garden. Chicago: University of Chicago Press, 2000.

UEBERSCHLAG, Georges. Les disciples de Linne: voyageurs, savants et penseurs. In: Actes $d u$ Colloque International des Lumieres. Lille: Publications de L’Université de Lille III, 1977. v.1. p.137-151.

URBANI, Bernardo; VILORIA, Ángel L.. Curiosidades para el Rey; Relación de objetos enviados en el siglo XVIII al Real Gabinete de Historia Natural de Madrid desde el Nuevo Mundo. Llull - Boletin de la Sociedad Española de Historia de las Ciencias, Madrid, n.25, p.196-220, 2002.

VALVERDE PÉREZ, Nuria. Actos de precisión: instrumentos científicos, opinión pública y economía moral en la ilustración española. Madrid: CSIC, 2007.

WAQUET, Françoise. Plus ultra; Inventaire des connaissances et progrés du savoir à l'époque classique. In: SCHAER, Roland (org.). Tous les savoirs du monde, Enciclopédies et bibliothèques, de Sumer au XXe. siècle. Paris: Bibliothèque Nationale de France, 1996. p.170-177.

WEBER, David J. Bárbaros; Los españoles y sus salvajes en la era de la Ilustración. Barcelona: Crítica, 2007.

Artigo apresentado em 18/09/2012. Aprovado em 02/06/2013 